
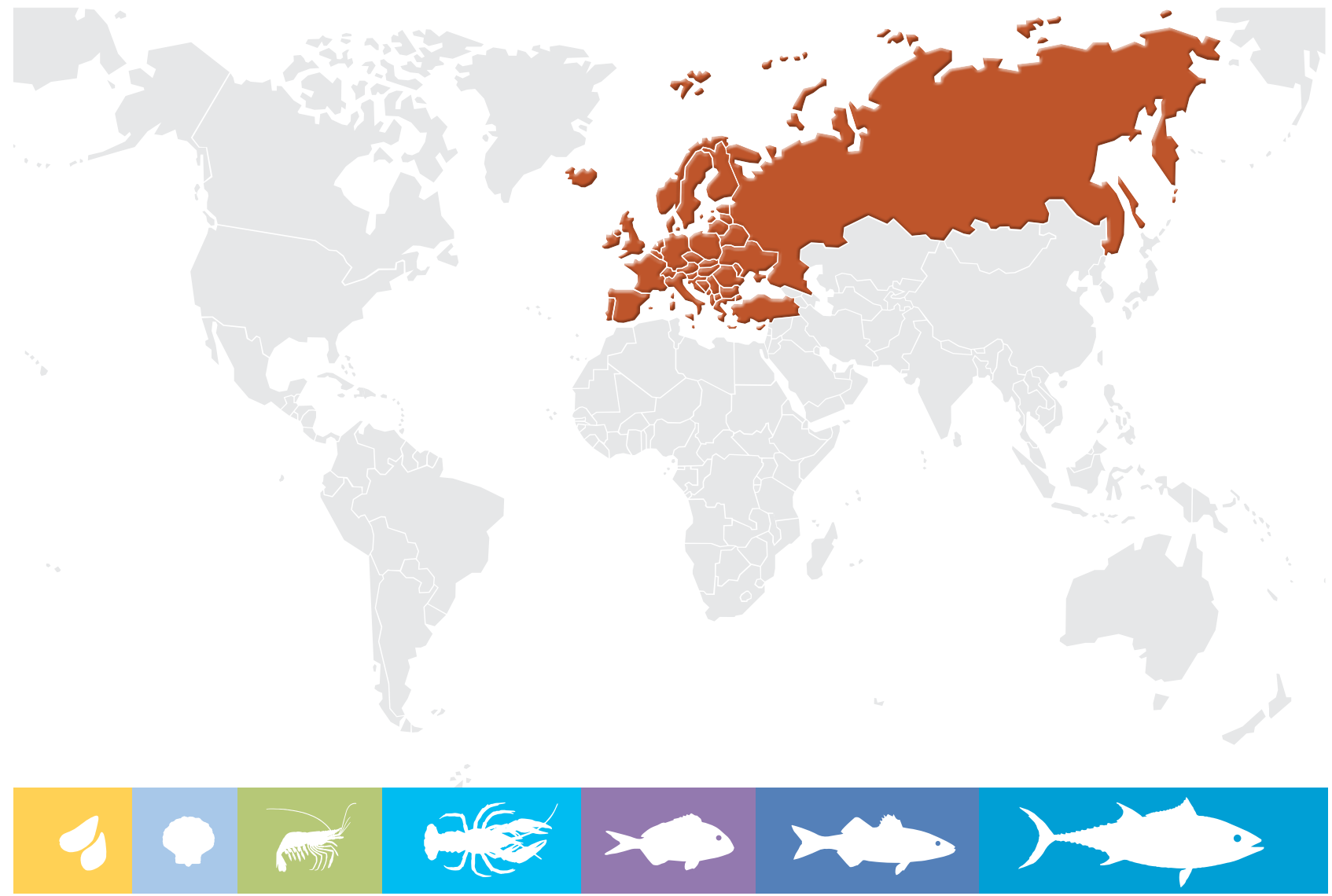



\title{
REGIONAL REVIEW ON STATUS AND TRENDS IN AQUACULTURE DEVELOPMENT IN EUROPE - 2015
}

\author{
by \\ Roy Clarke \\ Stirling Aquaculture Consultants \\ University of Stirling \\ Scotland, United Kingdom \\ and \\ John Bostock \\ Institute of Aquaculture \\ University of Stirling \\ Scotland, United Kingdom
}


The designations employed and the presentation of material in this information product do not imply the expression of any opinion whatsoever on the part of the Food and Agriculture Organization of the United Nations (FAO) concerning the legal or development status of any country, territory, city or area or of its authorities, or concerning the delimitation of its frontiers or boundaries. The mention of specific companies or products of manufacturers, whether or not these have been patented, does not imply that these have been endorsed or recommended by FAO in preference to others of a similar nature that are not mentioned.

The views expressed in this information product are those of the author(s) and do not necessarily reflect the views or policies of FAO.

ISBN 978-92-5-109652-9

(c) FAO, 2017

FAO encourages the use, reproduction and dissemination of material in this information product. Except where otherwise indicated, material may be copied, downloaded and printed for private study, research and teaching purposes, or for use in non-commercial products or services, provided that appropriate acknowledgement of FAO as the source and copyright holder is given and that FAO's endorsement of users' views, products or services is not implied in any way.

All requests for translation and adaptation rights, and for resale and other commercial use rights should be made via www.fao.org/contact-us/licence-request or addressed to copyright@fao.org.

FAO information products are available on the FAO website (www.fao.org/publications) and can be purchased through publications-sales@fao.org. 


\section{PREPARATION OF THIS DOCUMENT}

This Regional Review on Status and Trends in Aquaculture Development in Europe was prepared by Roy Clarke and John Bostock of the Institute of Aquaculture, University of Stirling. The authors greatly appreciate the contributions from the following experts: Elizabeth Sweetman (Ecomarine Ltd), Lara Barazi-Yeroulanos (Kefalonia Fisheries S.A.), Paul Featherstone (Marine Harvest), John and Nicki Holmyard (Offshore Shellfish Ltd.), Trevor Telfer (University of Stirling), Francis Murray (University of Stirling), Alistair Lane (European Aquaculture Society), Courtney Hough (Federation of European Aquaculture Producers and European Aquaculture Technology and Innovation Platform), Stefan Meyer (Kompetenznetzwerk Aquakultur (KNAQ) des Landes Schleswig-Holstein), Alexandra Neyts (Norwegian University of Science and Technology), Uwe Barg (FAO), Malcolm Beveridge (FAO), Eva Kovaks (FAO), Alessandro Lovatelli (FAO), Fabio Massa (FAO).

Finalization of the document, including technical editing, review and linguistic quality, was carried out by Brian Harvey, FAO Senior consultant. Xiaowei Zhou, FIAS, developed the main FAO statistical datasets with different levels of details used for the analysis in the document, and provided clarification to specific questions that arose in the course of its writing. The document was edited and formatted in line with FAO house style by Danielle Rizcallah who also assisted in the preparation of the final layout. 
FAO. 2017.

Regional review on status and trends in aquaculture development in Europe - 2015, by Roy Clarke and John Bostock. FAO Fisheries and Aquaculture Circular No. 1135/1. Rome, Italy.

\begin{abstract}
This update considers the wider European region comprising the 43 countries that were the object of the more detailed 2010 review of aquaculture in Europe (Váradi et al., 2011) and in particular notes significant changes related to aquaculture in that region since 2010. Aquaculture production data have been obtained from FAO Fisheries and Aquaculture Department, Fishery Information, Data and Statistics Unit.
\end{abstract}

The most notable development in the period has been the continuing increase in the production of Atlantic salmon (by 43 percent for the period 2009-2014), mainly in the Kingdom of Norway but with significant increases also in the Faroe Islands, the United Kingdom of Great Britain and Northern Ireland and the Russian Federation. Production technologies have undergone significant changes in this period with increasing use of very large scale Recirculating Aquaculture Systems (RAS) for the production of large smolts and in some cases for ongrowing fish to up to $1 \mathrm{~kg}$ in fresh water before transfer to sea cages. Despite the continuing increase in production, technical challenges remain, in particular the problem of sea lice infestation; the last five years have seen substantial commercial investment in the production and use of "cleaner fish" as biological controllers of lice numbers and in technology for other non-chemical treatment methods. The next five years are likely to see pilot trials of radical new production systems which are designed to minimise environmental impacts.

The production of European seabass and gilthead seabream in cages in the Mediterranean Sea has increased, but the ongoing consequences of the global financial crisis of 2007-2009; and the Eurozone sovereign debt crisis from the end of 2009 have to some extent limited growth in these sectors, particularly in the Hellenic Republic. However the Republic of Turkey, with its relatively fast-growing economy and non-EU status has been less constrained by the economic factors and has seen substantial increases in the production of both species.

Throughout Europe there has been continued interest, innovation and investment in small-scale RAS for a variety of species for which strong local markets are perceived to exist (examples include sturgeon, shrimp, barramundi, zander, European sea bass, perch and tilapia). Detailed information is difficult to obtain but the scale of this activity may best be described as "pilot". There has been a high failure rate in such projects, making short-term significant production growth from this sector unlikely.

The prescribed length and remit for this update do not allow for a complete summary of the status of all aquaculture sectors throughout Europe; the terms of reference require a focus on areas of significant change in the last 5 years. So, whilst sectors such as the extensive and semi-extensive production of carp represents the finfish species with the third highest production in the region (238 thousand tonnes in 2014, mainly in the Russian Federation), on the basis of information available to the authors there do not appear to have been significant developments in that sector in the last five years. Consequently, the culture of these species does not feature prominently in this review.

For complementary views on aquaculture in the Region, please see the Report from the COFI Sub-Committee on Aquaculture, Brasilia, Brazil, 3-9 October 2015, available at the following link: www.fao.org/cofi/4334104a74a5d167de0034251e8eaf83de443e.pdf 


\section{CONTENTS}

\section{Page}

PREPARATION OF THIS DOCUMENT

iii

ABSTRACT

ABBREVIATIONS AND ACRONYMS

iv

viii

1. SOCIAL AND ECONOMIC BACKGROUND OF EUROPE 1

1.1 Status and trends 1

1.1.1 Population 1

1.1.2 Wealth 1

1.1.3 Economic growth 2

1.2 Important issues 3

1.3 The way forward 3

2. GENERAL CHARACTERISTICS OF THE SECTOR 4

$2.1 \quad$ Status and trends 4

2.1.1 Status and trends for the region 4

$\begin{array}{ll}\text { 2.1.2 Status and trends by main producing countries } & 7\end{array}$

2.2 Important issues and success stories 9

2.2.1 Growth of salmon production 9

2.2.2 Mediterranean cage farming in European countries 9

2.3 The way forward 10

2.3.1 Salmon farming in Europe 10

2.3.2 Mediterranean cage farming 11

2.3.3 Opportunities in other European areas 12

3. RESOURCES, SERVICES AND TECHNOLOGIES 12

3.1 Status and trends 13

3.1.1 Salmon industry technology developments 13

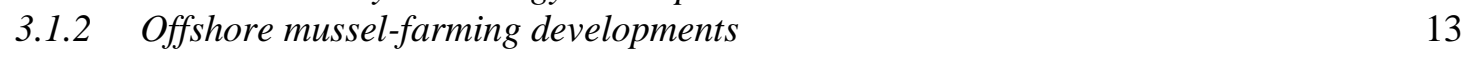

3.1.3 The Mediterranean bass and bream sector 14

3.1.4 Information and communications technologies for aquaculture 14

3.2 Important issues and success stories 15

3.2.1 Recirculating Aquaculture Systems (RAS) for salmon smolts and post-smolts 15

3.2.2 The use of cleaner fish in the salmon industry 15

3.2.3 The use of other non-chemical methods for lice treatment 15

3.3 The way forward 15

3.3.1 Projections for European Union aquaculture 15

3.3.2 Integrated Multi-Trophic Aquaculture systems (IMTA) 16

3.3.3 Moves offshore $\quad 16$

3.3.4 Shellfish hatchery and the potential for genetic selection 17

4. AQUACULTURE AND ENVIRONMENTAL INTEGRITY 17

4.1 Status and trends $\quad 17$

$\begin{array}{ll}\text { 4.1.1 Escapes from salmon cage farms } & 17\end{array}$

4.1.2 Escapes from Mediterranean cage farms 17

4.1.3 Sea lice in the Kingdom of Norway 18

4.2 Important issues and success stories 18

4.2.1 Commitment by the salmon industry to non-chemical sea lice treatments 18

4.3 The way forward 19

4.3.1 Salmon farms 19

5. MARKETS AND TRADE 19

5.1 Status and trends 19

$\begin{array}{lll}\text { 5.1.1 Production } & 19\end{array}$

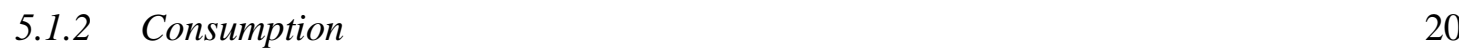

$\begin{array}{ll}\text { 5.1.3 Trade } & 21\end{array}$

$5.2 \quad$ Important issues and success stories 22 
5.2.1 Analysis of international promotional campaigns 22

5.2.2 Non-government standards $\quad 22$

5.3 The way forward 23

5.3.1 Increase in European aquaculture products on the European market 23

5.3.2 Increase in competitiveness of aquaculture products 23

6. CONTRIBUTION OF AQUACULTURE TO FOOD SECURITY AND SOCIAL AND 24

ECONOMIC DEVELOPMENT

6.1 Status and trends $\quad 24$

6.1.1 Regional economic development 24

6.1.2 Food security; feeding fish to fish; dependence upon capture fisheries 25

6.2 Important issues and success stories 26

6.2.1 Since 2010, farmed salmon have been net producers of marine protein and 26 marine oil

$\begin{array}{lll}\text { 6.2.2 } & \text { Traditional carp farming prospects } & 27\end{array}$

$\begin{array}{ll}\text { 6.2.3 Aquaculture in coastal lagoons } & 27\end{array}$

6.3 The way forward 27

6.3.1 A genetically modified plant oil is shown to be an effective substitute for fish oil 27 as a source of eicosapentaenoic acid in salmon diets

7. EXTERNAL PRESSURES ON THE SECTOR 28

$\begin{array}{lll}7.1 & \text { Status and Trends } & 28\end{array}$

7.1.1 Direct and indirect consequences of climate change 28

7.1.2 Disease outbreaks of epidemic proportions 29

7.1.3 Ecological changes not attributable to climate change 29

7.2 Important issues and success stories 29

7.2.1 Epidemiology and monitoring for early indications of disease presence 29

$\begin{array}{ll}7.2 .2 & \text { Disease surveillance and action planning } 29\end{array}$

7.2.3 Technologies and programmes for national or regional monitoring of the 29

7.3 The way forward 30

7.3.1 Increasing use of systems protected from environmental changes and events $\quad 30$

$\begin{array}{lll}\text { 7.3.2 } & \text { Future-proof system design } & 30\end{array}$

8. GOVERNANCE AND MANAGEMENT OF THE SECTOR 30

$\begin{array}{lll}8.1 & \text { Status and trends } & 30\end{array}$

8.1.1 Strategic planning in Europe by national and supra-national bodies 30

8.1.2 Regulatory and administrative structures 31

8.1.3 Allocation of zones for aquaculture 32

8.1.4 Financial support for development 32

8.1.5 Voluntary standards and sector governance 33

8.2 Important issues and success stories 33

8.2.1 Establishment of Norwegian "Green licences" 33

8.3 The way forward 34

9. AQUACULTURE CONTRIBUTION TO THE FAO STRATEGIC OBJECTIVES

$\begin{array}{lll}9.1 & \text { Status and trends } & 35\end{array}$

9.2 The way forward 36

10. REFERENCES

\section{LIST OF TABLES}

Table 1. Population growth in the European region and in the world

Table 2. Average annual GDP growth for the periods 2006 to 2010 and 2011 to 2015

Table 3. Aquaculture production increase 2010 to 2014 as CAGR for Europe and world 5

Table 4. Consumer preferences in EU28 countries 21

Table 5. Employment in aquaculture in selected European countries $\quad 24$

Table 6. Change in real price of main animal protein re-based to 100, 1980 - 2014 
Figure 1. GDP per capita PPP of countries in European region

Figure 2. European aquaculture production by mass and value 2005-2014

Figure 3. Production value in million US\$ of Atlantic salmon in Europe compared with all other species combined

Figure 4. Relative production (by mass) of principal aquaculture species in Europe, 2014

Figure 5. Production trends of major aquaculture species in Europe excluding Atlantic salmon

Figure 6. European aquaculture production by country, 2014

Figure 7. Norway aquaculture production by mass, 2005 to 2014

Figure 8. Aquaculture production trends of European countries excluding the Kingdom of Norway

Figure 9. European seabass production 2005-2014 by country

Figure 10. Gilthead seabream production 2005-2014 by country

Figure 11. Reported numbers of escape events from salmon farms in the Kingdom of Norway

Figure 12. Reported average numbers of female sea lice per fish in the Kingdom of Norway

Figure 13. Trend in combined fisheries and aquaculture production in Europe

Figure 14. European per capita consumption of fish and shellfish in 2007, 2011 and 2014

Figure 15. European trade flows in fish and shellfish

Figure 16. Production and employment trends in Norwegian aquaculture

Figure 17. Nutrient sources in Atlantic salmon diets, shown as a percentage of the total feed

Figure 18. Trend in dependency of farmed salmon diets on marine protein and marine oil 


\section{ABBREVIATIONS AND ACRONYMS}

\begin{tabular}{|c|c|}
\hline ASC & Aquaculture Stewardship Council \\
\hline AZA & allocated zones for aquaculture \\
\hline BIM & Bord Iascaigh Mhara \\
\hline CAGR & Compound Annual Growth Rate \\
\hline CEFAS & Centre for Environment, Fisheries and Aquaculture Science \\
\hline CFP & Common Fisheries Policy \\
\hline DHA & docosapentaenoic acid \\
\hline EAS & European Aquaculture Society \\
\hline EATiP & European Aquaculture Technology and Innovation Platform \\
\hline EC & European Commission \\
\hline EMFF & European Maritime and Fisheries Fund \\
\hline EPA & eicosapentaenoic acid \\
\hline ETPs & European Technology Platforms \\
\hline EU & European Union (Member Organization) \\
\hline EUMOFA & the European Market Observatory for Fish and Aquaculture Products \\
\hline FAO & Food and Agriculture Organization \\
\hline FIFG & Financial Instrument for Fisheries Guidance \\
\hline FTE & Full Time Equivalent \\
\hline GAP & Good Agricultural Practices \\
\hline GDP & Gross Domestic Product \\
\hline GFCM & General Fisheries Commission for the Mediterranean \\
\hline HLPE & High Level Panel of Experts \\
\hline ICES & International Council for the Exploration of the Sea \\
\hline iDREEM & Increasing industrial Resource Efficiency in European Mariculture \\
\hline IMTA & Integrated Multi-Trophic Aquaculture systems \\
\hline IPN & Infectious Pancreatic Necrosis \\
\hline LC-PUFAs & long-chain polyunsaturated fatty acids \\
\hline LIFDC & Low-Income Food-Deficit Countries \\
\hline MSC & Marine Stewardship Council \\
\hline NACEE & Network of Aquaculture Centres in Central-Eastern Europe \\
\hline NCE & Norwegian Centres of Expertise \\
\hline OECD & The Organisation for Economic Co-operation and Development \\
\hline PCR & polymerase chain reaction \\
\hline PPP & Purchasing power parity \\
\hline RAS & Recirculating Aquaculture Systems \\
\hline $\mathrm{R} \& \mathrm{D}$ & Research and Development \\
\hline ROC & receiver operating characteristic \\
\hline SAIC & Scottish Aquaculture Innovation Centre \\
\hline SOs & Strategic Objectives \\
\hline SRIA & Strategic Research and Innovation Agenda \\
\hline STECF & Scientific, Technical and Economic Committee for Fisheries \\
\hline UN & United Nations \\
\hline USDA & United States Department of Agriculture \\
\hline
\end{tabular}




\section{SOCIAL AND ECONOMIC BACKGROUND OF EUROPE}

\subsection{Status and trends}

\subsubsection{Population}

The total population of the European region ${ }^{1}$ in 2015 was 829 million representing 11.28 percent of the world population. The population growth of the region is considerably less than the world's as a whole and is shown in Table 1 for the last 5 years and the last 10 years.

Table 1. Population growth in the European region and in the world

\begin{tabular}{l|c|c}
\hline Region/country & Growth in period 2006-2015 & Growth in period 2011-2015 \\
\hline World & $11.4 \%$ & $4.86 \%$ \\
\hline European region & $2.86 \%$ & $1.34 \%$ \\
\hline Turkey & $14.5 \%$ & $7 \%$ \\
\hline European region excluding Turkey & $1.78 \%$ & $0.78 \%$ \\
\hline
\end{tabular}

Source: The World Bank, 2016a.

Almost half of the regional growth can be attributed to the Republic of Turkey, whose population has increased at a rate of about 1.7 percent per year for the last 5 years to 78.7 million in 2015 and which, uncharacteristically for the region, has 25.7 percent of its population aged 14 or under, compared with 15.9 percent for the rest of the European region.

\subsubsection{Wealth}

The region is relatively affluent compared with the world as a whole, as shown in Figure 1.

Only six countries in the region (the Republic of Serbia, the Former Yugoslav Republic of Macedonia, the Republic of Albania, Bosnia and Herzegovina, Ukraine and the Republic of Moldova) have per capita Gross Domestic Product (GDP) less than the world average in 2015. None of the countries in the region appear on the United Nations (UN) list of Low-Income Food-Deficit Countries (LIFDC) in 2015 (FAO, 2016a).

It is notable that amongst the countries experiencing the lowest growth in the last five years were the Hellenic Republic, the Portuguese Republic, the Republic of Italy and the Kingdom of Spain; all are Eurozone countries that received financial support from other Member States ("Bailouts”). Amongst the countries showing highest growth, the Republic of Latvia, the Republic of Lithuania, the Republic of Estonia and the Republic of Poland, all acceded to the European Union (Member Organization) (EU) in 2004 but did not adopt the Euro and as such may be showing the consolidating economic benefits associated with joining the European Union (Member Organization).

\footnotetext{
${ }^{1}$ The European region comprises 43 countries: the Republic of Albania, the Republic of Austria, the Republic of Belarus, the Kingdom of Belgium, Bosnia and Herzegovina, the Republic of Bulgaria, Channel Islands, the Republic of Croatia, the Republic of Cyprus, the Czech Republic, the Kingdom of Denmark, the Republic of Estonia, Faroe Islands, the Republic of Finland, the French Republic, the Federal Republic of Germany, the Hellenic Republic, Hungary, the Republic of Iceland, Ireland, the State of Israel, the Republic of Italy, the Republic of Latvia, the Republic of Lithuania, The Former Yugoslav Republic of Macedonia, the Republic of Malta, the Republic of Moldova, Montenegro, the Kingdom of the Netherlands, the Kingdom of Norway, the Republic of Poland, the Portuguese Republic, Romania, the Russian Federation, the Republic of Serbia, the Slovak Republic, the Republic of Slovenia, the Kingdom of Spain, the Kingdom of Sweden, the Swiss Confederation, the Republic of Turkey, Ukraine and the United Kingdom of Great Britain and Northern Ireland.
} 
Figure 1. GDP per capita $\mathrm{PPP}^{2}$ of countries in European region

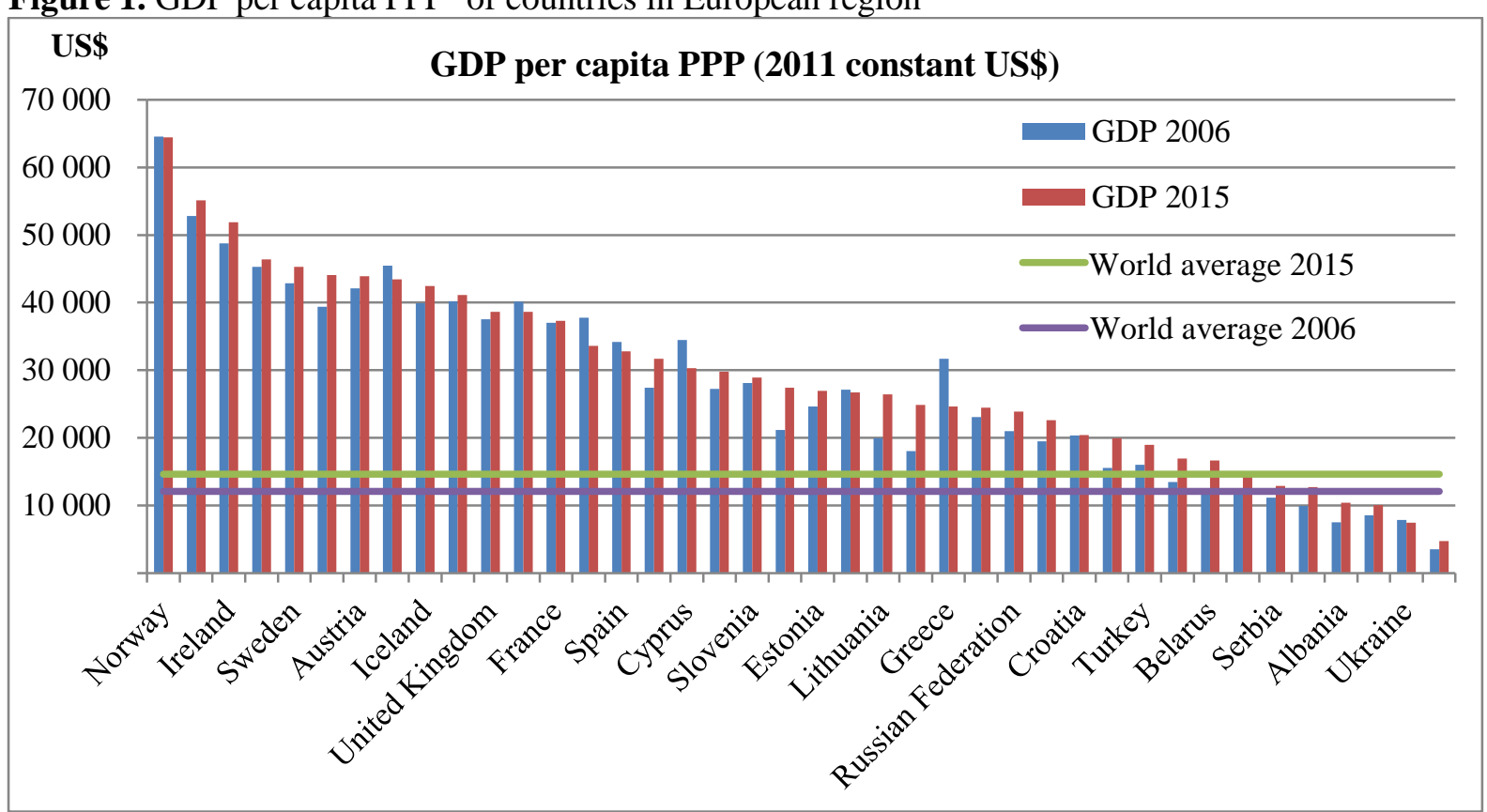

Source: World Bank databank.

\subsubsection{Economic growth}

The average annual GDP changes of the countries in the European zone over the periods 2006-2010 and 2011-2015 are shown in Table 2.

Table 2. Average annual GDP growth for the periods 2006 to 2010 and 2011 to 2015

\begin{tabular}{|c|c|c|c|c|c|c|c|c|}
\hline \multirow[b]{2}{*}{ Country } & \multicolumn{2}{|c|}{$\begin{array}{c}\text { Average GDP } \\
\text { Annual growth (\%) }\end{array}$} & \multirow[b]{2}{*}{ Country } & \multicolumn{2}{|c|}{$\begin{array}{c}\text { Average GDP } \\
\text { Annual growth (\%) }\end{array}$} & \multirow[b]{2}{*}{ Country } & \multicolumn{2}{|c|}{$\begin{array}{c}\text { Average GDP } \\
\text { Annual growth (\%) }\end{array}$} \\
\hline & $\begin{array}{c}2006 \text { to } \\
2010\end{array}$ & $\begin{array}{c}2011 \text { to } \\
2015\end{array}$ & & $\begin{array}{c}2006 \text { to } \\
2010\end{array}$ & $\begin{array}{l}2011 \text { to } \\
2015\end{array}$ & & $\begin{array}{c}2006 \text { to } \\
2010\end{array}$ & $\begin{array}{l}2011 \text { to } \\
2015\end{array}$ \\
\hline Turkey & 3.31 & 4.42 & Albania & 5.18 & 1.93 & France & 0.79 & 0.85 \\
\hline Moldova & 3.35 & 3.88 & Montenegro & 4.59 & 1.84 & Denmark & 0.09 & 0.66 \\
\hline Estonia & 0.07 & 3.66 & Hungary & -0.15 & 1.71 & Netherlands & 1.31 & 0.62 \\
\hline Lithuania & 1.59 & 3.61 & Norway & 0.94 & 1.71 & Slovenia & 1.87 & 0.56 \\
\hline Latvia & 0.03 & 3.50 & Germany & 1.30 & 1.53 & Serbia & 2.73 & 0.37 \\
\hline Ireland & 0.89 & 3.44 & Bulgaria & 3.18 & 1.52 & Finland & 0.94 & 0.05 \\
\hline Israel & 4.36 & 3.27 & Switzerland & 2.25 & 1.50 & Spain & 1.10 & -0.14 \\
\hline Poland & 4.73 & 2.95 & $\begin{array}{l}\text { Czech } \\
\text { Republic }\end{array}$ & 2.51 & 1.34 & Croatia & 0.58 & -0.45 \\
\hline Iceland & 1.38 & 2.57 & $\begin{array}{l}\text { Bosnia and } \\
\text { Herzegovina }\end{array}$ & 2.90 & 1.32 & Italy & -0.27 & -0.71 \\
\hline $\begin{array}{l}\text { Macedonia, } \\
\text { FYR }\end{array}$ & 4.02 & 2.40 & Belarus & 7.35 & 1.24 & Portugal & 0.63 & -0.93 \\
\hline Romania & 3.10 & 2.38 & $\begin{array}{l}\text { Russian } \\
\text { Federation }\end{array}$ & 3.72 & 1.21 & Cyprus & 2.49 & -1.78 \\
\hline $\begin{array}{l}\text { Slovak } \\
\text { Republic }\end{array}$ & 4.91 & 2.38 & Malta & 2.38 & 1.80 & Ukraine & 1.38 & -2.22 \\
\hline $\begin{array}{l}\text { United } \\
\text { Kingdom }\end{array}$ & 0.43 & 2.10 & Austria & 1.33 & 1.02 & Greece & -0.24 & -3.84 \\
\hline Sweden & 1.67 & 2.00 & Belgium & 1.41 & 0.93 & & & \\
\hline
\end{tabular}

Source: data from World Bank databank.

\footnotetext{
${ }^{2}$ The purchasing power parity (PPP) theory uses the long-term equilibrium exchange rate of two currencies to equalize their purchasing power. PPP takes into account the relative cost of living and the inflation rates of the countries being compared, rather than simply gross domestic product (GDP) comparison.
} 
The best-performing economy in the European region in terms of GDP growth for 2010 to 2015 was that of the Republic of Turkey, the third-largest country by population (78.7 million) and also the third-highest producer of aquaculture products in the region. The Republic of Turkey is experiencing rapidly rising prosperity. In less than a decade, per capita income in the country has nearly tripled and now exceeds US\$10 500. During the decade 2002-2012, extreme poverty fell from 13 to 4.5 percent and moderate poverty fell from 44 to 21 percent while access to health, education, and municipal services vastly improved for the less well-off (The World Bank, 2016b).

\subsection{Important issues}

The last 10 years has been a tumultuous period in terms of economic and social events in the European region and, as will be discussed in later sections, the consequences for aquaculture production, growth and sales have been significant. The main events that had a significant effect upon the economies of countries in the region during the period were the global financial crisis of 20072009 and the Eurozone sovereign debt crisis from the end of 2009.

The global financial crisis of 2007-2009 had particularly severe consequences in Europe, with some countries going into prolonged economic recession at various times between 2008 and 2013. This contributed to the Eurozone sovereign debt crisis in which several European countries were unable to maintain arrangements for repayment of national debt from the end of 2009, or to achieve suitable refinancing arrangements; the result was the need for third-party support (bailouts) from other Eurozone countries or from the European Central Bank. The consequences of the crisis were felt at all levels of society and many individuals lost earnings and employment, with inevitable consequences for retail trade, including trade in fish products.

Amongst the European countries which have been supported through financial bailouts, the Hellenic Republic and the Kingdom of Spain are major aquaculture producers in Europe. In the Hellenic Republic in particular, the Eurozone debt crisis contributed to a major re-structuring of the European seabass and gilthead seabream industries, as leading companies were forced to seek solutions to deal with large debts (Tallaksen, 2014a). The capital re-structuring across the aquaculture sector constrained capital investment for expansion of production. The Hellenic Republic's European seabass and gilthead seabream sector, whilst of considerable importance as a provider of employment in rural coastal areas, has stagnated somewhat (see Section 2).

The embargo imposed by the Russian Federation on the import of prescribed goods from countries that had supported sanctions against the Russian Federation in September 2014 had an impact on the trade of aquaculture products from all of Europe. The effects were particularly significant in the Kingdom of Norway and the Republic of Turkey.

\subsection{The way forward}

The OECD predicts (OECD, 2016) that the economic prospects for the Kingdom of Norway - the dominant aquaculture country in Europe - will remain weak as petroleum investment falls. Output from non-oil sectors in the Kingdom of Norway will pick up, with exports boosted by the present depreciated currency against the US\$. Whilst this economic factor clearly has short-term implications for the Norwegian aquaculture industry, other factors such as environmental concerns are likely to be of greater impact. These issues are considered in detail later in the report.

For the European Union area, the European Commission forecast (EC, 2016) is for modest growth with the main impetus coming from domestic demand. For individual European countries with significant aquaculture industries the summary forecast is as follows:

- the Hellenic Republic - growth will return later in 2016;

- the French Republic - moving slowly towards a more self-sustained economy;

- the Kingdom of Spain - growth to ease but remain robust; 
- the Republic of Italy - moderate growth to continue;

- the United Kingdom of Great Britain and Northern Ireland - moderation in growth with rising inflation;

- the Russian Federation - a protracted recession with a long path to recovery; and

- the Republic of Turkey - domestic demand remains the driver of growth.

\section{GENERAL CHARACTERISTICS OF THE SECTOR}

\subsection{Status and trends}

\subsubsection{Status and trends for the region}

Aquaculture production in the European region in 2014 was 3192 million tonnes with a value of US $\$ 14.73$ billion. This represents 3.16 percent of the world's aquaculture production by mass and 8.87 percent by value from a region with 11.28 percent of the world's population.

Production in the region has increased over the last 10 years as shown in Figure 2.

Figure 2. European aquaculture production by mass and value 2005-2014

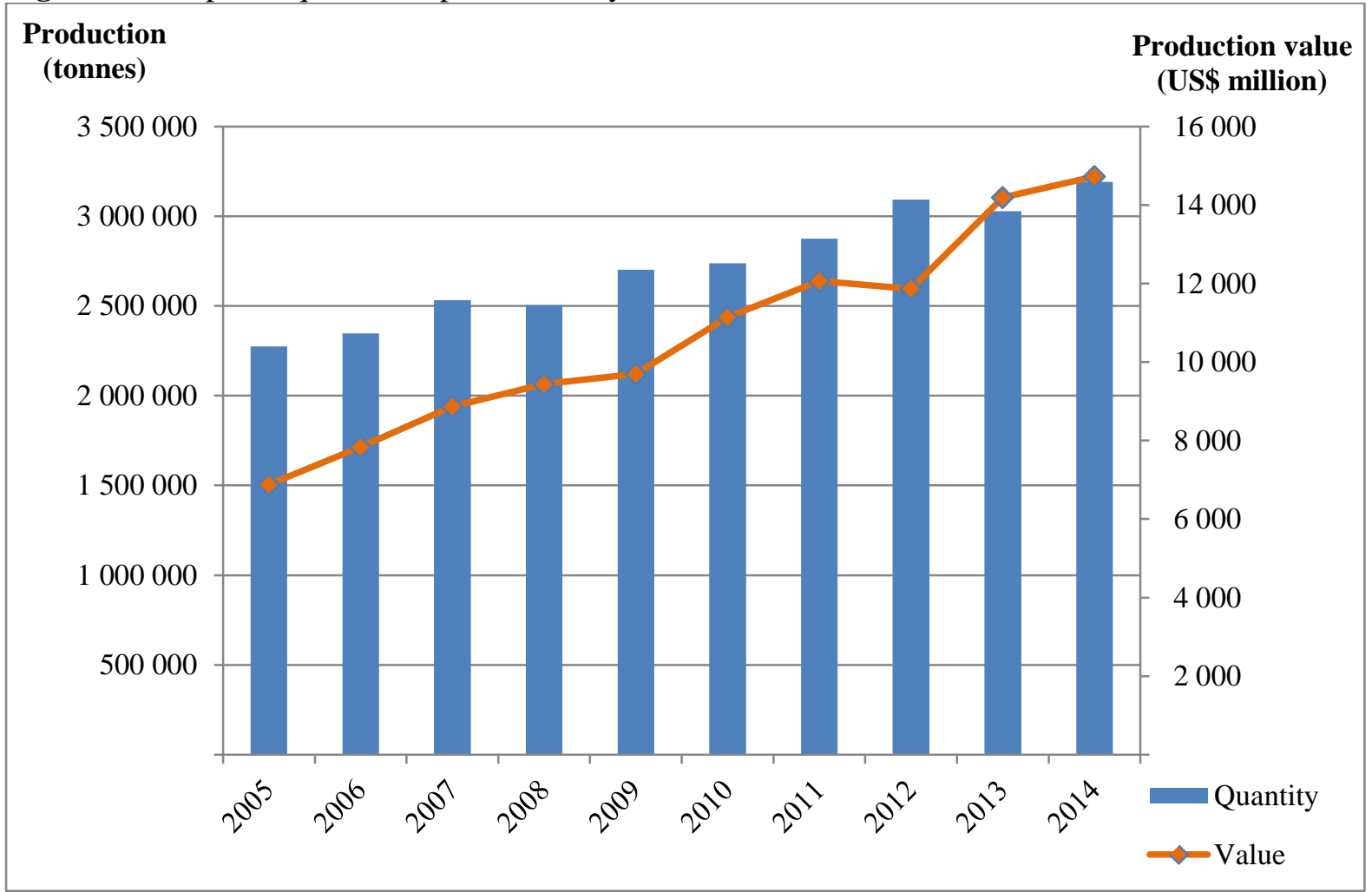

Source: FAO, 2016b.

Production by mass has increased over the last 10 years by 40 percent and by value by 114 percent. There has been a slight reduction in the rate of increase in the last 5 years.

The Compound Annual Growth Rates (CAGR ${ }^{3}$ s) for 2010 to 2014 by mass and value for Europe are compared with world growth rates (as CAGRs) in Table 3.

\footnotetext{
${ }^{3}$ Compound Annual Growth Rate (CAGR) is the mean annual growth rate over a period of more than one year. CAGR $=\left((\text { end value/beginning value })^{1 / n}-1\right)(n=$ no of years $)$.
} 
Table 3. Aquaculture production increase 2010 to 2014 as CAGR for Europe and world

\begin{tabular}{l|c|c} 
Aquaculture production increase 2010 to 2014 & Europe & World \\
\hline CAGR (mass) & $3.1 \%$ & $5.3 \%$ \\
\hline CAGR (value) & $5.7 \%$ & $5.7 \%$ \\
\hline
\end{tabular}

Source: FAO, 2016b.

The difference between world and European figures is explained by the domination of production in Europe by the relatively high value Atlantic salmon as shown in Figure 3.

Figure 3. Production value in million US\$ of Atlantic salmon in Europe compared with all other species combined

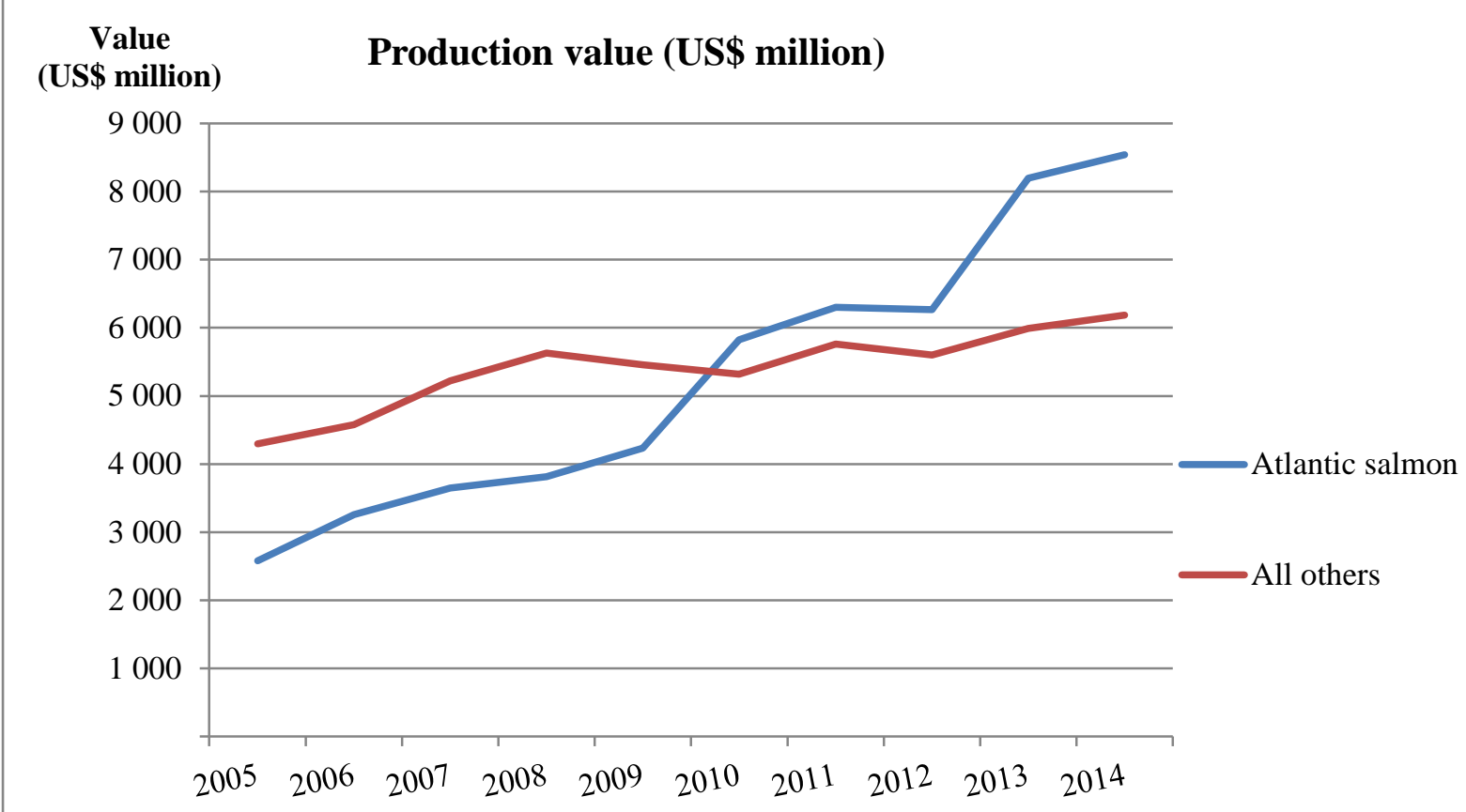

Source: FAO, 2016b.

By 2010, the value of Atlantic salmon production exceeded the combined value of all other aquaculture production in Europe; by 2014 it accounted for 58 percent of the value of all species.

The relative production by mass of the principal aquaculture species in 2014 is shown in Figure 4. 
Figure 4. Relative production (by mass) of principal aquaculture species in Europe, 2014

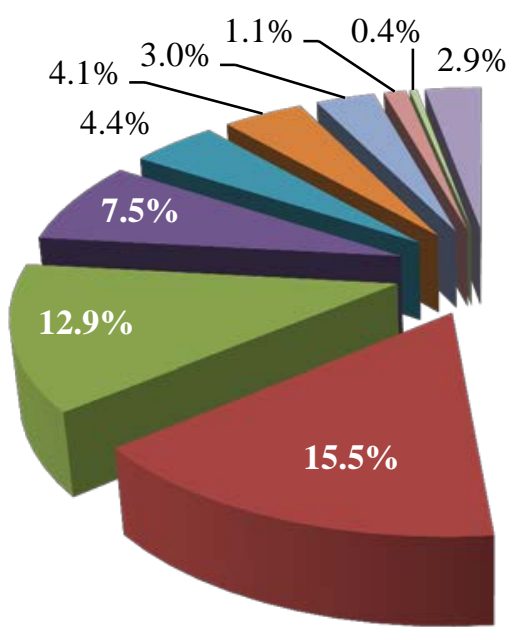

- Atlantic salmon

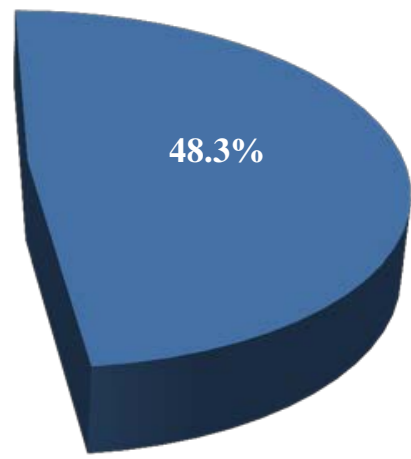

- Mussels

- Rainbow trout

- Carps

- Europen sea bass

- Gilthead sea bream

- Oysters

n Clams

$\square$ Turbot

- Others (227)

Source: FAO, 2016b.

When Atlantic salmon is excluded, the production trend by mass of the aquaculture species in the region is shown in Figure 5.

Figure 5. Production trends of major aquaculture species in Europe excluding Atlantic salmon

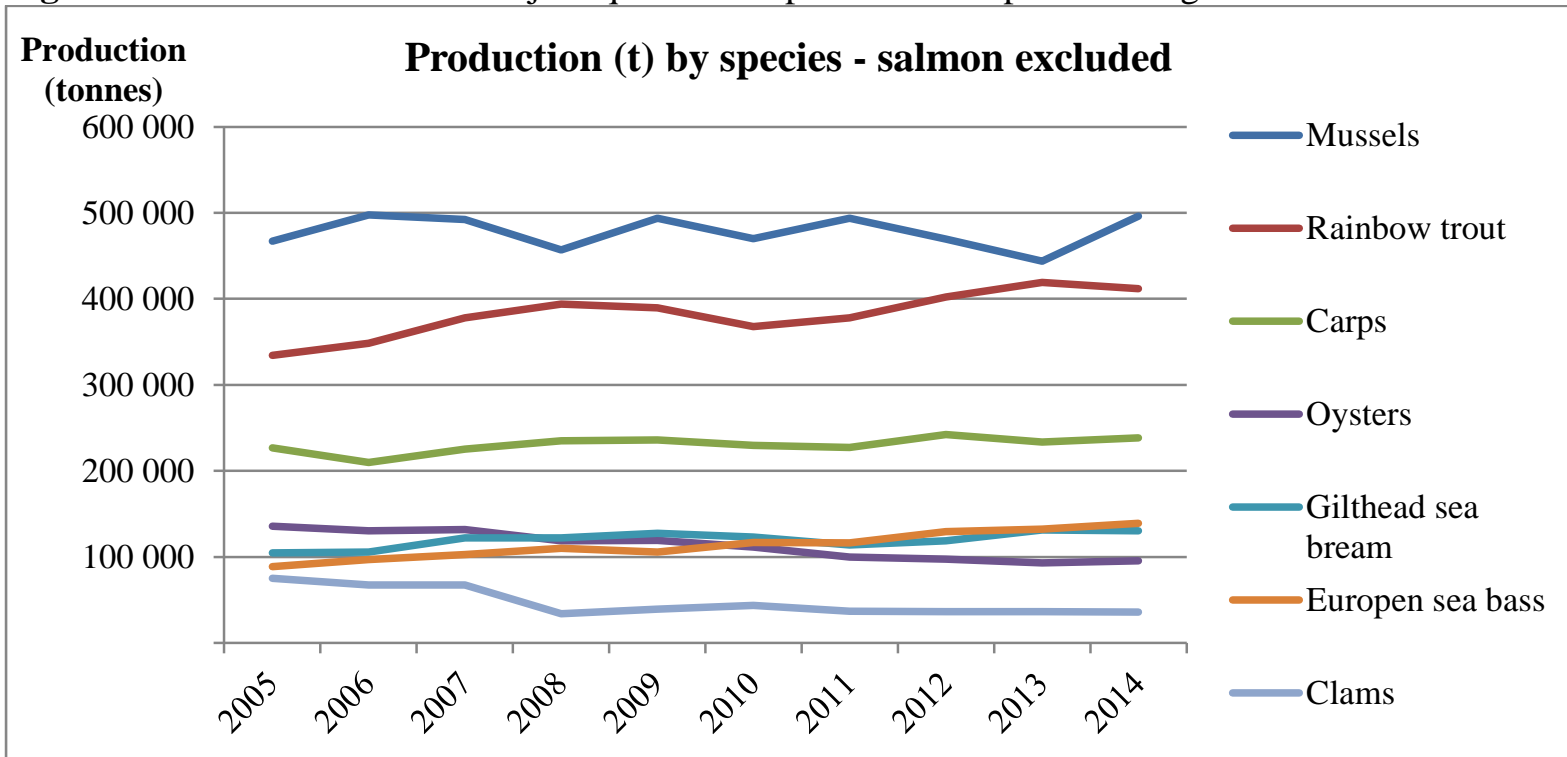

Source: FAO, 2016b.

It can be seen that over the last 10 years, apart from Atlantic salmon, only rainbow trout, European seabass and gilthead seabream have shown fairly consistent, if small, increases in production. Production of clams and oysters has reduced, mussel production has shown significant year-on-year variation around a steady median and carp production has been stable.

When considering aquaculture production by country, not surprisingly the Kingdom of Norway overshadows all other individual countries because it is the principal producer of Atlantic salmon. Figure 6 shows 2014 production, by mass and by value, of the main producing countries in the region. 
Figure 6. European aquaculture production by country, 2014

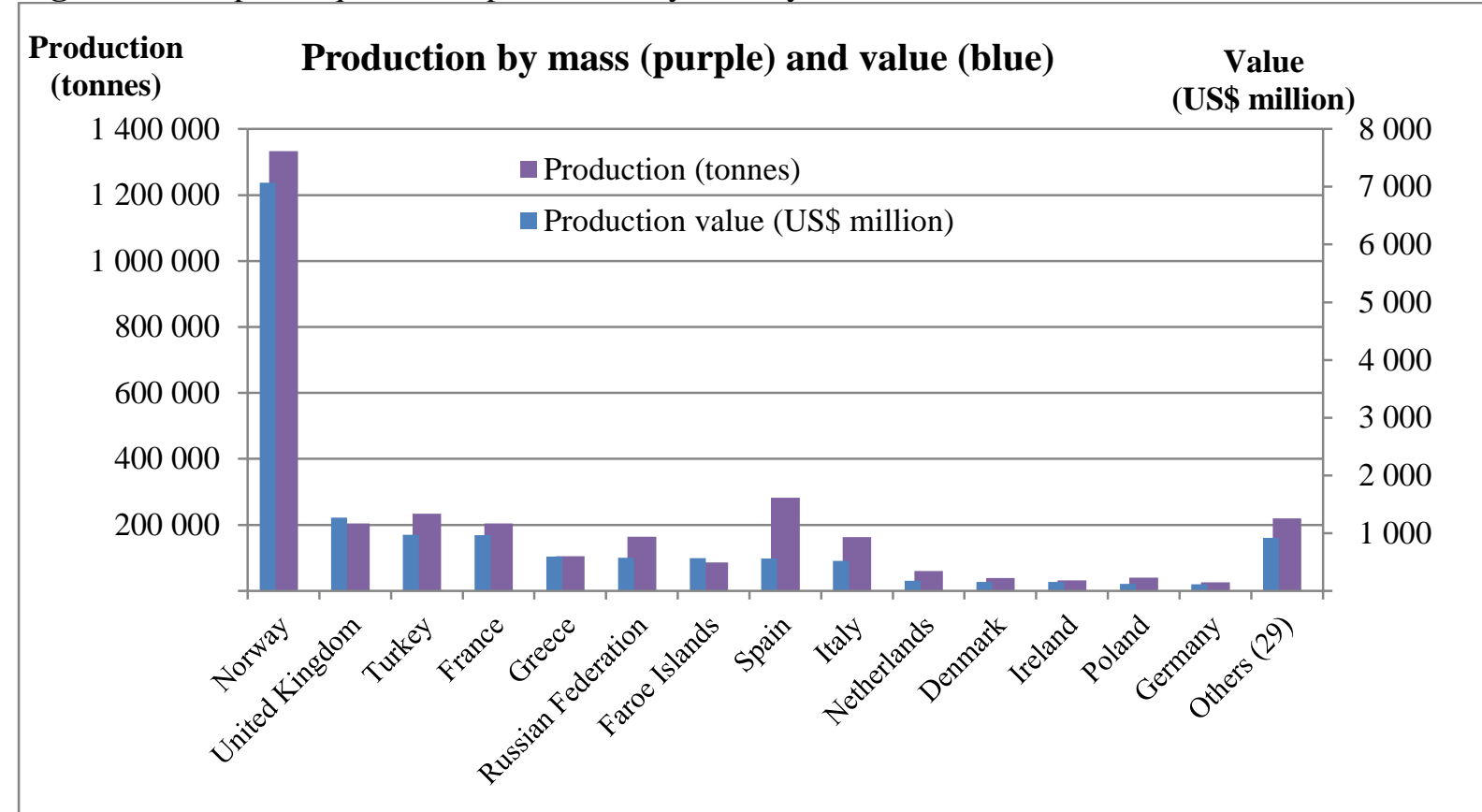

Source: FAO, 2016b.

\subsubsection{Status and trends by main producing countries}

The Kingdom of Norway's production for the last 10 years is shown in Figure 7.

Figure 7. Norway aquaculture production by mass, 2005 to 2014

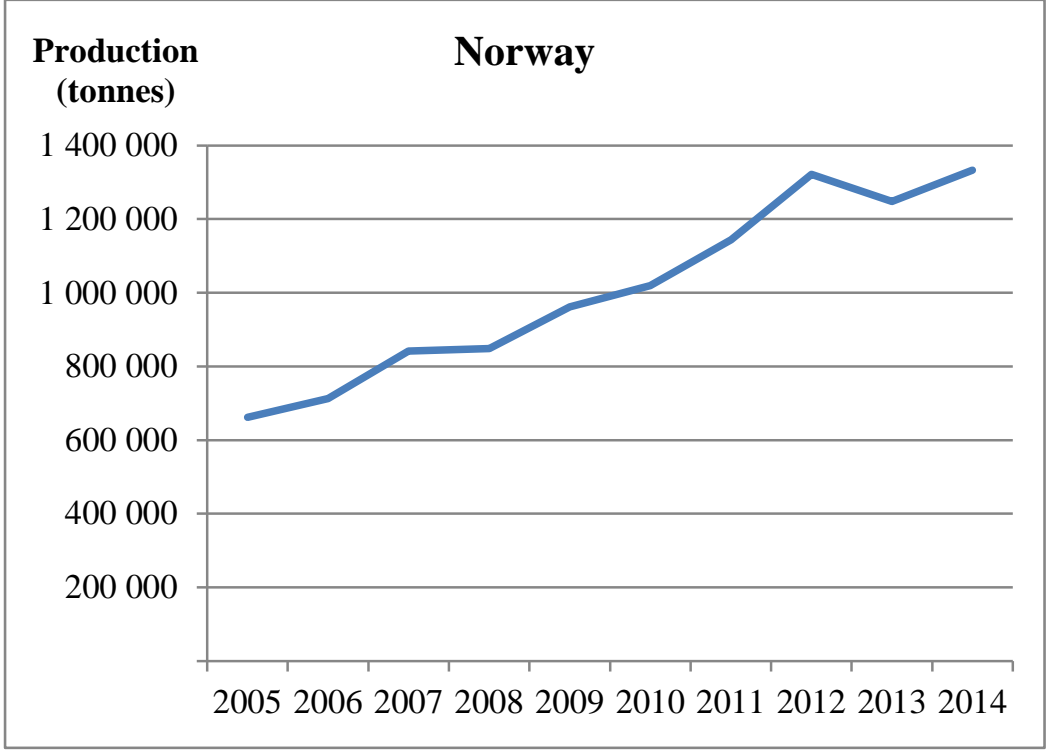

Source: FAO, 2016b
In 2014, the Kingdom of Norway produced 42 percent of aquaculture products in Europe by mass and 48 percent by value, making it the world's ninth largest producer by mass and the sixth by value - remarkable for a country with a population of 5.2 million. Production from the Kingdom of Norway in 2014 comprised 94.5 percent Atlantic salmon and 4.1 percent rainbow trout (69 000 tonnes), with both species predominantly being grown to market size in floating cages in marine environments.

Production trends in the other 12 European countries that individually produce more than 1 percent of total European production are shown in Figure 8. 
Figure 8. Aquaculture production trends of European countries excluding the Kingdom of Norway

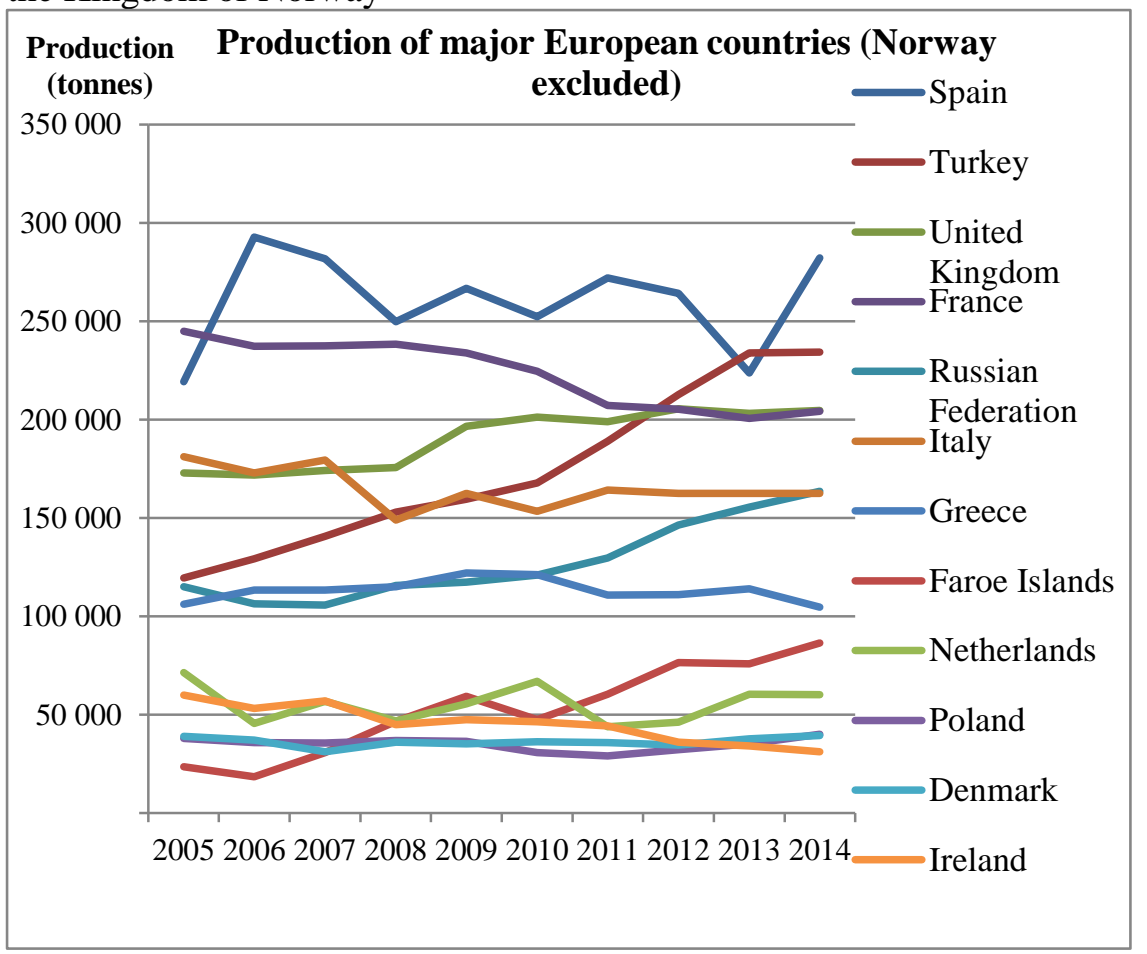

Source: FAO, 2016b.
The Kingdom of Spain's aquaculture production in 2014 comprised 78 percent mussels, 6 percent sea bass, 6 percent gilthead seabream and 5 percent rainbow trout with the remaining 5 percent mainly oysters and various high-value marine fish including turbot. Mussels are grown primarily using raft systems. There has been a steady build-up of cage culture of European seabass over the last 20 years. Gilthead seabream production has been more or less stable for the last 5 years.

The Republic of Turkey's 2014 production comprised 49 percent rainbow trout, 32 percent European seabass and 18 percent sea bream. The Republic of Turkey is the largest producer of European seabass in the region and the bass industry in the Republic of Turkey is showing steady and continuing growth, having doubled to 74000 tonnes in 10 years. The Republic of Turkey's rainbow trout sector has also grown at a similar rate over the last 10 years, doubling from 2005 to 2009 (100 000 tonnes) then continuing to increase at a slightly slower rate to 2014. Gilthead seabream production has grown steadily but at a slower rate, increasing by 50 percent over the last 10 years to 42000 tonnes in 2014.

The United Kingdom of Great Britain and Northern Ireland was the fourth largest producer in Europe in 2014 with production comprising 81 percent Atlantic salmon, 11 percent mussels and 7 percent rainbow trout. The salmon sector, following a period of steady growth since 2005, has slowed to marginal growth over the last few years. The United Kingdom of Great Britain and Northern Ireland (specifically Scotland) is the second largest producer of salmon in Europe with 165000 tonnes in 2014. The mussel sector uses various production systems, with managed beds in England and Wales being the source of the majority of production and a smaller but expanding rope-grown production in Scotland.

The French Republic's aquaculture production comprised 37 percent each of mussels and oysters, with the only other large category ( $>2$ percent of the total) being rainbow trout at 17 percent with common carp (2 percent), European seabass (1.2 percent) and gilthead seabream (0.8 percent) accounting for much of the balance. The total French production has declined over the last 10 years with oyster production accounting for almost all the decline, falling from 120000 tonnes to 76000 tonnes between 2005 and 2014 mainly as a consequence of oyster herpes virus which devastated production in 2008.

Production in the Russian Federation in 2014 comprised 64 percent carps, 11 percent Atlantic salmon and 15 percent rainbow trout. Carp production shows wide annual variation, reportedly declining by 8.5 percent from 2005 to 2009, then increasing by 18 percent to 2014. There is recent increased activity in the production of rainbow trout both in freshwater and marine sites, as well as in the 
production of Atlantic salmon, mainly in the Barents and White Seas (USDA, 2016). Trout production has increased steadily to 25000 tonnes with a CAGR of 11 percent. Atlantic salmon production has grown to 18675 tonnes in the last 7 years.

From 2009 to 2014 the total aquaculture production in the Republic of Italy remained flat at about 160000 tonnes. The Republic of Italy is the largest producer of clams in Europe (mainly Japanese carpet shell) with a volume of 31000 tonnes (19.4 percent of total production) while the production of blue mussels represented 48.6 percent of the total (around 79000 tonnes). The production of rainbow trout and other salmonids reached about 34400 tonnes while the production of European seabass and gilthead seabream accounted respectively for 6700 tonnes and 5400 tonnes.

\subsection{Important issues and success stories}

\subsubsection{Growth of salmon production}

The outstanding feature of European aquaculture from 2010 to 2015 was the continued growth of the salmon industry which in 2010 surpassed in value the combined total of all other farmed species in Europe (US\$5.8 billion out of a total of US\$11.1 billion) and by 2015 had reached US\$8.54 billion, representing 58.1 percent of Europe's total aquaculture production by value.

Farmed salmon and trout represent 70 percent of total Norwegian seafood exports and seafood is the country's third largest export product behind oil and oil-related goods and services, both of which are experiencing rapid decline (Hersoug, 2015). The salmon industry has grown with the help of investment into new and improved technologies and large-scale dedicated engineering developments. Investment has come from an increasingly small number of large companies that have grown through acquisition of smaller operations. Many of the major salmon production companies are listed on national stock markets and have international interests, producing salmon in more than one region of the world. The industry in the Kingdom of Norway is a significant employer, with around 10000 people working directly in the production and processing sectors and a further 14000 jobs in associated supply or service sectors. Many of these jobs have been created in fragile, marginal coastal communities and as such underpin the preservation of social structures in rural areas that have experienced a significant reduction in fishing and fishing-related employment.

\subsubsection{Mediterranean cage farming in European countries}

Cage farming in the Mediterranean continues to be dominated by European seabass and gilthead seabream production in the Hellenic Republic and the Republic of Turkey. The change in production by various Mediterranean countries that are significant producers of for the two species is shown in Figures 9 and 10.

It can be seen that apart from production of European seabass and gilthead sea bream in the Republic of Turkey and European seabass in the Kingdom of Spain, there has been little significant or sustained production increase throughout the last decade. Undoubtedly, economic conditions, particularly in the Eurozone countries and notably in the Hellenic Republic, have hindered development (see Section 1) but several other factors have also been proposed as the explanation for the failure of this sector so far to achieve its perceived potential. At a joint workshop of the European Aquaculture Technology and Innovation Platform (EATiP) and the European Aquaculture Society (EAS) in 2014 (EATiP, 2014) it was noted that in addition to the financial crisis and economic situation in many Mediterranean countries in the region there was also a lack of communication and collaboration within the sector regarding technical and scientific issues. It was also noted that this was partly because the sector functioned in many countries and across many cultures using many languages, yet the product was concentrated in one market. Areas highlighted for urgent development included a better understanding of and provision for nutritional needs at all growth stages, collaborative programmes for selection and breeding for optimal characteristics and generic market development. 
Following the sovereign debt crisis in the Hellenic Republic, many aquaculture companies went through financial re-structuring, typically with banks converting debt to equity. This has led to the consolidation of many smaller companies; larger companies with new management and ownership structures are emerging (for example, see Tallaksen 2014a, Tallaksen 2014b). A degree of stability has returned to the sector, though a general lack of confidence in market prices and a degree of caution being applied to expansion strategies is resulting in very slow growth (Lara BaraziYeroulanos, Chief Executive Officer, Kefalonia Fisheries S.A., personal communication), as well as inertia in the licence allocation system (see Section 8).

Figure 9. European seabass production 2005-2014 by country

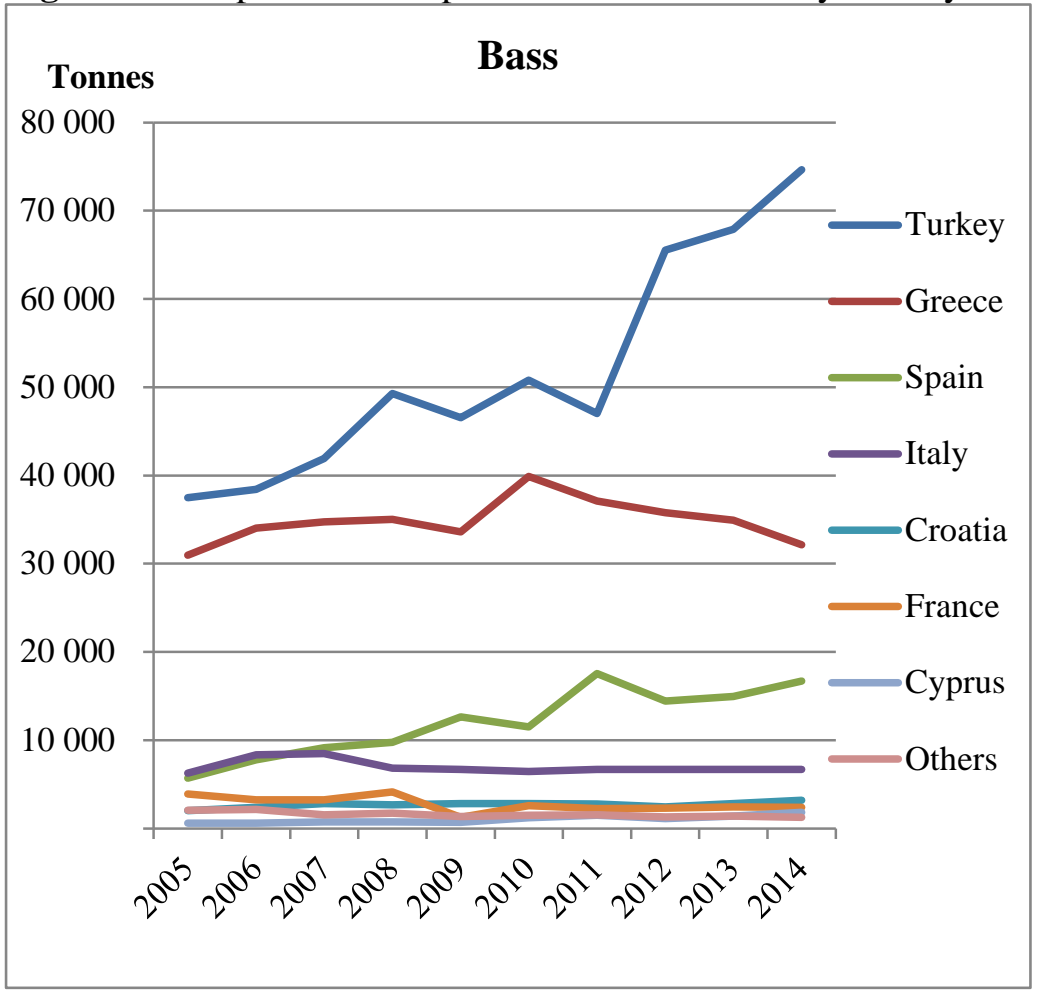

Source: FAO, 2016b

Figure 10. Gilthead seabream production 2005-2014 by country

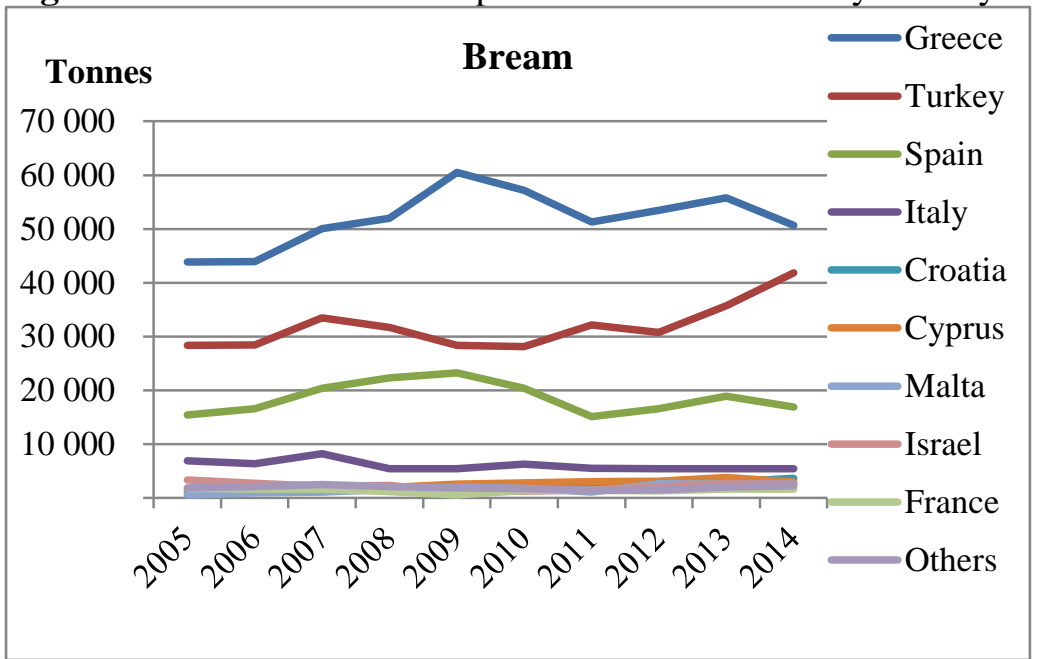

Source: FAO, 2016b
Nevertheless, some companies are progressively investing in larger-scale systems and greater automation and mechanisation which should ultimately result in more efficient production and the capacity for growth.

\section{$2.3 \quad$ The way forward}

\subsubsection{Salmon farming in Europe}

Because of the predominance of the salmon industry in Europe, the absolute prospects for growth in the region are heavily influenced by that sector. There is a generally held view in the salmon industry that it has reached something of a watershed. After spectacular growth over 45 years, mainly in the Kingdom of Norway, it seems to have approached the limits for expansion using conventional methods and there are pressing reasons why alternative methods need to be developed if the sector is to continue to grow in a sustainable manner. Whilst clearly representing an economic success, continuing growth has been opposed by several sectors of Norwegian society. Losses from parasitic lice, escapes and concern about the impact on the environment have all compounded the pressure on the industry to seek new production techniques which allow for greater control of the growing environment, containment and treatment of waste - and which can be deployed further offshore than present systems. Control of sea lice is widely recognized within the industry as the major threat to the 
financial viability of salmon production and the industry is investing heavily in solutions to these challenges. These developments are discussed further in Sections 4 and 8.

The Norwegian Government continues in its aspiration that the Kingdom of Norway become the world's leading seafood nation (Hersoug, 2015). Within this strategic plan there is the objective to grow the salmon sector on the basis of economic and environmental sustainability to three times its present size by 2030 and five times by 2050. If the 2030 target is to be achieved, the annual rate of production needs to increase by 7.6 percent CAGR. It seems unlikely this will be the case for the next few years, because new and appropriate technologies need to be developed and proved. Despite these aspirations of the Norwegian government the future growth of the salmon sector will be determined in the next five years by the degree of success of strategies to ameliorate the impact of sea lice. If successful treatments or management methods are developed and adopted the industry can continue to grow; if not, the industry could stagnate.

The growth of the salmon aquaculture industry elsewhere in Europe (mainly the United Kingdom of Great Britain and Northern Ireland and the Faroe Islands) is likely to mirror growth in the Kingdom of Norway; there is significant co-ownership of Norwegian, Scottish and Faroese companies and they face common challenges.

Forecasts for growth in the European Union member states were estimated by the European Union technology platform EATiP in 2012. Conclusions were presented in a vision document (EATiP, 2012) which underpinned a Strategic Research and Innovation Agenda (SRIA) that in turn informed the Strategic Guidelines for the Sustainable Development of European Aquaculture (European Commission, 2013). The projections were made on a species-by-species basis; EATiP projections for Atlantic salmon in Europe were more modest than those of the Norwegian government, predicting a CAGR of 3.5 percent that implies a doubling in production from 2010 to 2030 to a total in 2030 of 2.32 million tonnes.

\subsubsection{Mediterranean cage farming}

European seabass and gilthead seabream production in the Hellenic Republic and the Republic of Turkey are likely to continue to dominate Mediterranean aquaculture for the foreseeable future. The rate of growth in the Hellenic Republic has been slower than expected (see Section 2.2.2) and much will depend upon the rate of technological advancement, for example in feed technology and selective breeding programmes (see Section 3). Additionally, expansion can only take place if the market can absorb the extra production and this will depend upon, amongst many factors, greater efficiency of production and hence lower production cost, better generic marketing of product and improved retail product development. EATiP's projection (EATiP, 2014) for growth of the European seabass and gilthead bream sectors was a CAGR of 3.8 percent, implying a 20-year increase from 2010 to 248000 tonnes (European seabass) and 262000 tonnes (gilthead seabream).

Whilst cage farming dominates the production of marine and brackish species in Mediterranean European countries including the production of European seabass and gilthead seabream, some production also continues from coastal lagoon systems, mainly in the Kingdom of Spain and the Republic of Italy. The Republic of Italy dominates the production from such systems with a total for both species of 4900 tonnes in 2014 (FAO, 2016b). Other countries contribute approximate a further 2000 tonnes for both species. There is no significant increasing trend for these brackish water production systems.

In addition a small production from the Republic of Turkey of European seabass takes place in the Black Sea area and from the French Republic and the Kingdom of Spain from Atlantic marine sites.

The hopes for the development of a Mediterranean-based full-cycle bluefin tuna aquaculture industry anticipated by Váradi et al. (2011) have made only small steps forward. The penning and fattening industry has recovered somewhat as catch quotas have increased gradually after a low of 5790 tonnes 
in 2011 to 11203 tonnes in 2016 (FAO, 2016b). However, formulated diets are not yet in commercial use. Further progress has been made in Europe with captive breeding, larval rearing and the subsequent nursery phase, but more time and funding are needed to achieve sufficiently high survival rates for commercially viable production (De la Gándara, Ortega and Buentello, 2016).

\subsubsection{Opportunities in other European areas}

According to a recent United States Department of Agriculture Global Agriculture Information Network report (USDA, 2016), the Russian Federation has vast unexploited fresh water resources and the development of the aquaculture sector is well below potential levels. Development is largely left to private enterprise that has so far focused on marine salmon farm developments in the Barent and White Sea areas. Since 2014, the Russian Federation has implemented a national plan (Russian Federation, 2014) for the development of its fisheries sector, including growth goals for the aquaculture industry. The programme aims to support the development of mariculture, particularly the increase of shellfish production, and the reinforcement of the freshwater farming with the production of sturgeon. Among the main targets of the plan, production is planned to reach 410000 tonnes by 2020 from 140000 tonnes produced in 2012.

Efforts are ongoing especially in the Mediterranean marine sector to develop new fish species for aquaculture, for example as supported by the European Union project DIVERSIFY ${ }^{4}$. The rationale is that market prices of European seabass and gilthead seabream are often depressed and lead to low or even negative profits. Diversification to new species would broaden the market and provide greater opportunities for profit. There are many species for which the farming technology exists, and several species have been trialled, the most commercially successful of which has been meagre (Argyrosomus regius) for which 2550 tonnes are recorded by FAO for 2014. Meagre has been farmed since 1997 (the French Republic and the Republic of Italy); the production fluctuates year-by-year and has not yet taken off at large scale although it is produced in many Mediterranean countries and particularly in the Hellenic Republic. Current efforts are also focusing on species of yellowtail or amberjack. Whilst it is possible that a new candidate species will become a major product category (in the way that Pangasius production developed very rapidly in Viet Nam), it is necessary for a species to be successfully domesticated, attractive to the market and economic to produce. It has proved challenging to achieve all these criteria in all but a few cases. Teletchea (2015) found that the top ten farmed marine fish account for 90 percent of marine finfish aquaculture production. As an indicator of failures, 35 of the 100 marine species that have been farmed are no longer being produced. The success of farmed salmon has in part been due to product diversification rather than species diversification, with farms providing raw materials that can be transformed into many different products for sale to consumers. A similar situation exists with terrestrial livestock where a very small number of species comprise the bulk of farmed production. High value or niche species can appear an attractive target for aquaculture, but if production is successful, prices quickly fall given the smaller market volumes that can be achieved, and profitability is again a critical factor.

\section{RESOURCES, SERVICES AND TECHNOLOGIES}

Production technology developments and trends over the last five years are considered for three sectors: the salmon industry, offshore mussel farming and the Mediterranean bass and bream sector. There is increasing activity in the application of management information systems, for which a summary is also presented.

\footnotetext{
${ }^{4}$ www.diversifyfish.eu
} 


\subsection{Status and trends}

\subsubsection{Salmon industry technology developments}

The Atlantic salmon industry is the most highly developed form of large-scale intensive aquaculture (Shepherd and Little, 2014) and it continues to strive for productivity growth through technological advancement. Over the most recent 5 year period for which production data is available, we estimate that just under US $\$ 0.5$ billion has been invested in sea cage site production equipment (based on the financial model in Marine Harvest (2016) and production data from FAO (2016b)), purely to accommodate the on-going growth in production.

However, the sector has now reached a point where innovation is crucial. Site capacities have more or less been reached and concerns about environmental impact and in particular the challenges posed by sea lice mean that there is little willingness by the regulatory authorities to consent to the allocation of new sites or the expansion of production using current practices (see Section 8). Industry's response to this constraint has been an unprecedented level of investment in technology development and adoption that is transforming the state of the art in technology, equipment and operating practices. For example, the same 5-year period has seen rapid adoption of new smolt production technologies utilising Recirculating Aquaculture Systems (RAS) (see section 3.2.1); based on the review of Garay Krogh (2016) we estimate that about 25 new RAS systems have been built since 2009 at a (conservative) average cost of US\$20 million each. This implies a further US\$0.5 billion investment in the salmon sector. We can therefore say that simply for the expansion of the industry and the development of new RAS smolt units, the Atlantic salmon industry has made capital investment of about US\$1 billion over the last 5 years.

This transformation is by no means complete - indeed, the industry is currently exploring many alternatives for production systems, technologies and operating practices in order to identify the most effective regimens; progress over the next five years will prove crucial to determining the future shape of the industry. Key technology trends include the use of cleaner fish for lice control, the use of other non-chemical lice treatments such as hydrolicing and thermolicing, the development of large-scale RAS systems for highly-controlled smolt and post-smolt production and the evaluation of novel designs for true offshore rearing systems. For summary of novel production systems currently under investigation, see Marine Harvest (2016).

\subsubsection{Offshore mussel-farming developments}

The potential development of "offshore aquaculture" or "open ocean aquaculture" has often been described as the Blue Revolution; that is, a change having the potential to make advances equivalent to those made on land in the so-called Green Revolution (ICES, 2012). However, to date there has been little movement to extreme offshore locations (Jansen et al., 2016) partly because of unsuitability of equipment and difficulties in managing systems in exposed conditions. The ICES workshop (ICES, 2012) noted that offshore longline mussel farming had been established since the mid-1990s at various locations off the Mediterranean coast, the Atlantic coast and the northern coast of the French Republic. Various types of submerged or submersible longline were used. However, it was reported that production from these sites has declined (ICES, 2012).

In 2014 a new large-scale offshore mussel-farming venture was established in the English channel. It adapted New Zealand technology for system moorings and for bulk on-deck handling of production equipment and for processing product; it has also worked with manufacturers to develop custom-made longline floats and equipment suitable for the prevailing conditions. The farm has the potential to produce 10000 tonnes per year and early indications are that growing conditions are highly suitable. The first two years’ growth performance has surpassed original expectations (Holmyard, 2015).

The scale of this single venture is far larger than any previous single mussel farm system in Europe. The business model of very large scale production capability, coupled with the application of very 
efficient bulk handling and processing from adequate vessels and a direct route to market, if successful, could lead the way for the uptake of similar production units elsewhere in Europe. Parallels can be drawn between this approach and the modern state of salmon farming, where substantial capital investment is required and economies of scale are exploited in operating procedures, resulting in highly competitive operating costs.

\subsubsection{The Mediterranean bass and bream sector}

A joint EATiP/European Aquaculture Society meeting (EATiP, 2014) concluded that technical progress of the industry was poor. It was noted that there was a need for more research into nutritional requirements, improvement in the quality of juveniles through broodstock selection and breeding and access to better sites to ensure good growing environments.

Janssen et al. (2015) summarised the findings of the EU-funded programmes Aquatrace ${ }^{5}$ and Fishboost (2014). It was noted that unlike the salmon industry - where specialised breeding companies have produced and continue to improve high-performing strains that are widely used throughout the industry - for bass and bream, most producers have breeding programmes integrated with production. Five companies operated breeding programmes for European seabass and eight for gilthead seabream with the number of selected generations used ranging from two to eight for bass and one to five for bream. From theoretical improvements in growth performance it was inferred that the theoretical relative improvement in farmed bass under current conditions would be two times and for bream 1.5 to 2, thereby indicating the potential benefits from a co-ordinated and well-resourced regional breeding programme for the sector. For comparison, the growth advantage for farmed vs wild salmon is three-fold.

\subsubsection{Information and communications technologies for aquaculture}

Modern finfish aquaculture is increasingly dependent on good management information systems for monitoring, control and optimisation. In the last five years there has been significant development of software systems to support improved operational efficiency. The European market leaders in this area are $\mathrm{AKVA}^{6}$ who produce software tools for management and traceability of stocks, control for feeding systems and process control; aquaManager ${ }^{7}$ who provide a comprehensive range of products which operate across multiple platforms, and Mercatus ${ }^{8}$, a Norwegian pioneer in cloud-based systems.

A relatively new company in this area is Aquinetix that is developing simple-to-use software for mobile phones/tablets which focuses on improving performance, especially in feed management. The entire system is cloud-based with possibilities for company benchmarking and other added-value applications ${ }^{9}$.

There is believed to be substantial benefit to be gained from improved analysis of the data that are now commonly collected on farms through automated monitoring and control systems. This makes use of the emerging tools for data-mining of large data sets. There are two EU-funded projects working in this area with the aim of commercialising software products; they are Findit ${ }^{10}$ and Aquasmart ${ }^{11}$. There is corresponding development of robust sensors, wireless communications and integration with video image analysis and data from other systems such as weather, wave and climate data. An example of practical application of such advances is the now-routine use of automated systems for counting and size/biomass assessment.

\footnotetext{
5 https://aquatrace.eu/

${ }^{6}$ www.akvagroup.com/products/cage-farming-aquaculture/software

${ }^{7}$ www.aqua-manager.com

${ }^{8}$ www.steinsvik.no/en/products/e/seaculture/software/mercatus/

${ }^{9}$ www.aquanetix.co.uk

${ }^{10}$ http://findit.pepite.be

${ }^{11}$ www.aquasmartdata.eu
} 


\subsection{Important issues and success stories}

\subsubsection{Recirculating Aquaculture Systems (RAS) for salmon smolts and post-smolts}

Various attempts have been made to use Recirculating Aquaculture Systems (RAS) since the mid1970s with rather limited success (Murray, Bostock and Fletcher, 2014). Systems have often been heralded as the means to grow a range of fish species in any location but technical challenges coupled with high energy and investment costs have resulted in many failed projects. The challenges faced by the salmon industry have intensified the drive to find innovative solutions in which optimum use is made of limited freshwater resources and discharge consents, and also in order to allow for optimum management practices in the timing of the transfer of fish to the sea for grow out. For the last decade, serious attempts to exploit these perceived benefits of RAS and technology development have continued rapidly, requiring substantial investments from the main production companies.

RAS is rapidly becoming the standard method for smolt and post-smolt production in the Kingdom of Norway and Chile. Garay Krogh (2016) noted that in 2003 there were only three RAS hatcheries in the Kingdom of Norway; by 2008 there were nine and by December 2015 there were 34 with a further five under construction. Typical unit capacity of current projects is $12-20$ million smolts per year. The approximate capital investment cost is around US\$60 million for a typical complete system.

A recognised benefit of using RAS to produce large post-smolts is that these fish require less time in the grow-out phase compared to the conventional approach, thereby greatly reducing the susceptibility to lice infection, with the added benefit of more efficient utilisation of the capacity limits of the growout sites. This approach, or variations of it, is rapidly being adopted by sections of the industry to improve efficiency.

\subsubsection{The use of cleaner fish in the salmon industry}

An operating practice that has become widespread over the last five years is the use of cleaner fish in the cages to feed on lice. Farmed ballan wrasse (Labrus bergylta) is widely acknowledged as a sustainable means of controlling sea lice (Torrissen et al., 2013) as is the lumpsucker (Cyclopterus lumpus). However, considerable R\&D is required in order to meet the nutritional and health needs of these relatively new farmed species and to maintain or enhance their behaviour of seeking and consuming lice in the environment of a salmon cage. Substantial research funds are being allocated both by public and private sector sources to develop such knowledge and to identify sustainable and reliable operating regimes.

\subsubsection{The use of other non-chemical methods for lice treatment}

The main salmon production companies have also led the way in the development of non-chemical lice management regimes. The last 12 months have seen multi-million dollar investments, in the Kingdom of Norway and Scotland, in Hydrolicer and Thermolicer machines installed in dedicated well-boats; the machines use rapid fresh water or thermal shock to kill lice (BBC, 2016).

\subsection{The way forward}

\subsubsection{Projections for European Union aquaculture}

The European Union aquaculture technology platform (EATiP) conducted an exercise (EATip, 2012) that projected aquaculture production and technology trends in the European Union region to 2030. Results were summarised by Bostock et al. (2016) as follows:

- There will be a productivity/competitiveness tendency towards the use of larger cages, particularly in offshore locations, seen as the increasing location trend for both Mediterranean and cold water farming. 
- Coastal pond aquaculture will decline or stagnate, principally because of lower yields and competition for space (availability and licences).

- Indoor marine recirculation systems will increase for hatcheries, but because of the investment and energy costs are less likely for on-growing, principally because of the cost differential with cage production (both Mediterranean and cold water); RAS may play a role in the development of some higher value species such as sole and shrimp.

- Freshwater pond production will stabilize or increase, dependent on a combination of market demand, diversification activities and recognition of environmental services.

- Intensive flow-through systems for freshwater species will decline, with the longer-term activity in this sector being determined by a combination of market demand, water availability and diversification towards specialised/niche markets (e.g. organic labelling), where lower intensity is preferred.

- Freshwater recirculation systems will increase, notably for high-value species (sturgeon, pike-perch) and potentially for warmwater species that can be produced at high density (e.g. African catfish, eel, tilapia).

- Shellfish production will continue to be dominated by supported/suspended cultivation systems.

\subsubsection{Integrated Multi-Trophic Aquaculture systems (IMTA)}

EATIP (2012) also predicted a progressive integration of integrated multi-trophic aquaculture systems (IMTA) with extended and enlarged cage systems, though they note that not only does financial viability need to be demonstrated but also that present legal frameworks and licensing conditions would need to be elaborated by region or coastal area in order to accommodate such developments. IMTA is the practice of growing fish alongside other aquatic organisms - for example shellfish, aquatic plants or algae - the production of which can benefit from any nutrient enrichment or organic waste that emanates from the fish system. Such integrated systems are very common in extensive aquaculture systems in Asia but have not yet proved their efficacy in more intensive, commercial systems in Europe. Naturally such systems have great appeal from an environmental perspective and have tended to receive a great deal of attention from advocacy groups, scientists and policy-makers.

The collaborative European project iDREEM (Increasing industrial Resource Efficiency in European Mariculture) ${ }^{12}$ has received substantial funding from the European Union (Member Organization) to develop and demonstrate new IMTA technologies and systems for application in Europe. A large scale IMTA operation is currently being piloted in the Kingdom of Denmark by the KOMBI project ${ }^{13}$. The farm aims to be 'zero impact'. The project team predict that harvesting $7000-9000$ tonnes of mussels will recover 100 percent of nutrients released by 2105 tonnes of rainbow trout each year.

\subsubsection{Moves offshore}

The challenges of dealing with sea lice have become so extreme that the industry is being forced to seek radical new approaches in order to continue to grow. Novel designs of floating cages have been proposed throughout the history of cage aquaculture including submersible, semi-submersible, fully enclosed or ship-based floating tanks. Quite suddenly, many such ideas are being put into practice to move the industry further offshore in order not only to ameliorate the environmental impact of release of nutrients and organic matter but also to reduce the impact of lice infestations. The self-cleaning capacity of a site improves with greater depth, so there is greater opportunity offshore to keep the release of nutrients and organic matter below the self-cleaning capacity (Ross et al., 2013). According to a recent trade press report (Ramsden, 2016) Marine Harvest's Chief Executive Officer announced that four offshore designs for large scale production are being evaluated by the company and the most cost-effective will be developed to full production specifications. Designs include a converted cargo vessel, a closed system (named "the egg") with 90percent of the structure beneath the surface, a

\footnotetext{
12 www.idreem.eu/cms/

${ }^{13}$ www.kombiopdraet.dk - in Danish
} 
floating, circular, fully-closed system ("the donut") in which fish swim against a forced current and a flexible, fully-submersible cage with a capacity for 200000 fish. Similarly, Leroy Seafood Group has applied for permits to develop its offshore "pipe farm" concept which is stated to have a capacity of 7020 tonnes and which will cost around US\$80 million. Other major producers including Norway Royal Salmon, Aker and SalMar have also announced novel offshore development projects (for summary see Marine Harvest, 2016).

\subsubsection{Shellfish hatchery and the potential for genetic selection}

In 2016 an investigation began into the technical and commercial viability of a shellfish hatchery in Shetland (the United Kingdom of Great Britain and Northern Ireland) that could eventually enable broodstock selection for desirable traits such as high meat yields, strong shells, disease resistance, optimised growth rate amongst many others (Arthur, 2016; Ashton, 2016). Technical feasibility of a mussel hatchery has recently been demonstrated for green-lipped mussels (Perna canaliculus) in New Zealand ${ }^{14}$ and the Shetland project aims to adapt the technology and apply new science to confer a competitive advantage to commercial shellfish production using hatchery-reared selected stock. The project is at a very early stage and financial viability is yet to be investigated (Gregg Arthur, Aquaculture Manager, North Atlantic Fisheries College Marine Centre, personal communication).

\section{AQUACULTURE AND ENVIRONMENTAL INTEGRITY}

With the dominance of salmon production in European aquaculture, the most serious aspects of environmental sustainability are those that relate to the proliferation of salmon farming - in particular sea lice and escapes. Escapes are also a concern in the Mediterranean Sea cage sector.

\subsection{Status and trends}

\subsubsection{Escapes from salmon cage farms}

Negative effects of escapes include ecological interactions and the genetic impacts of inter-breeding of farmed and wild salmon which can result in reduced lifetime success, lowered individual fitness, and decreases in production over at least two generations. Data from fisheries and returns from anglers show that the proportions of farmed salmon in catches fluctuated between 25 percent and 55 percent for coastal catches and 10 percent to 40 percent in fjords (Thorstad et al., 2008).

The causes of escapes and engineering and management solutions to prevent them have been rigorously documented (Prevent Escape, 2014). A Norwegian standard (Standard Norge, 2009) for cage farm equipment has been developed and has been progressively implemented from 2006 with an immediate positive effect. The trend in escapes from Norwegian farms is shown in Figure 11 below.

Escapes in 2006 represented 0.35 percent of total stock whereas by 2009 they represented 0.07 percent. The principles of the Norwegian Standard 9415 (Standard Norge, 2009) for cage farming equipment have subsequently been incorporated in a new Scottish Technical Standard introduced in June 2015 (Marine Scotland, 2015).

\subsubsection{Escapes from Mediterranean cage farms}

The Cordis project Prevent Escape (Prevent Escape, 2014) also considered escapes from marine cages of Mediterranean species. It was noted that there was evidence of inter-breeding of escaped bass and bream with wild stocks and potential for negative consequences including transfer of diseases and pathogens. Authors also noted anecdotal evidence of gilthead seabream spawning in cages, representing "escapes through spawning”.

\footnotetext{
${ }^{14}$ see www.spatnz.co.nz
} 
Figure 11. Reported numbers of escape events from salmon farms in the Kingdom of Norway

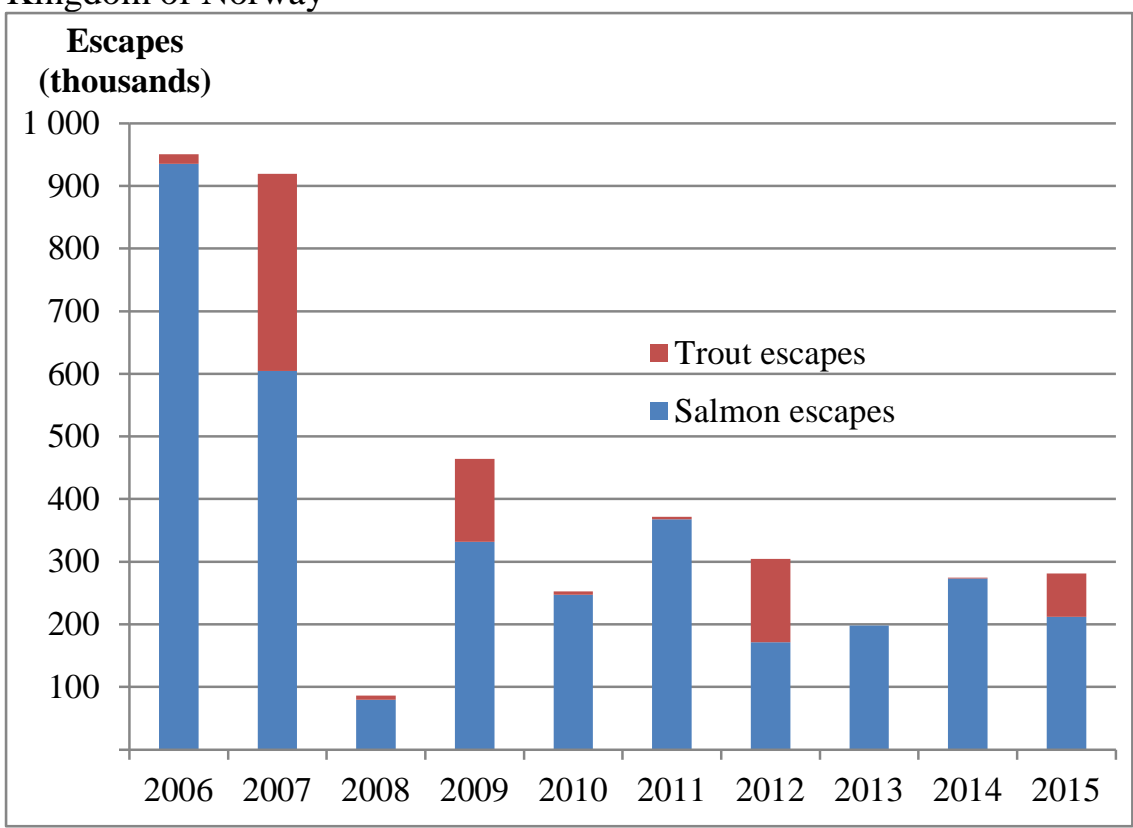

4.1.3 Sea lice in the Kingdom of Norway

A rigorous monitoring programme for sea lice levels on Norwegian farms has been in place since 2002. Data are reported on the openaccess website mysalmon.no.

Figure 12 shows that the average number of lice has fallen from its peak in 2010 to below 0.2 in 2015. It is noted that 0.2 is the maximum allowable level before intervention.

Source: Norway, 2016

Figure 12. Reported average numbers of female sea lice per fish in the Kingdom of Norway

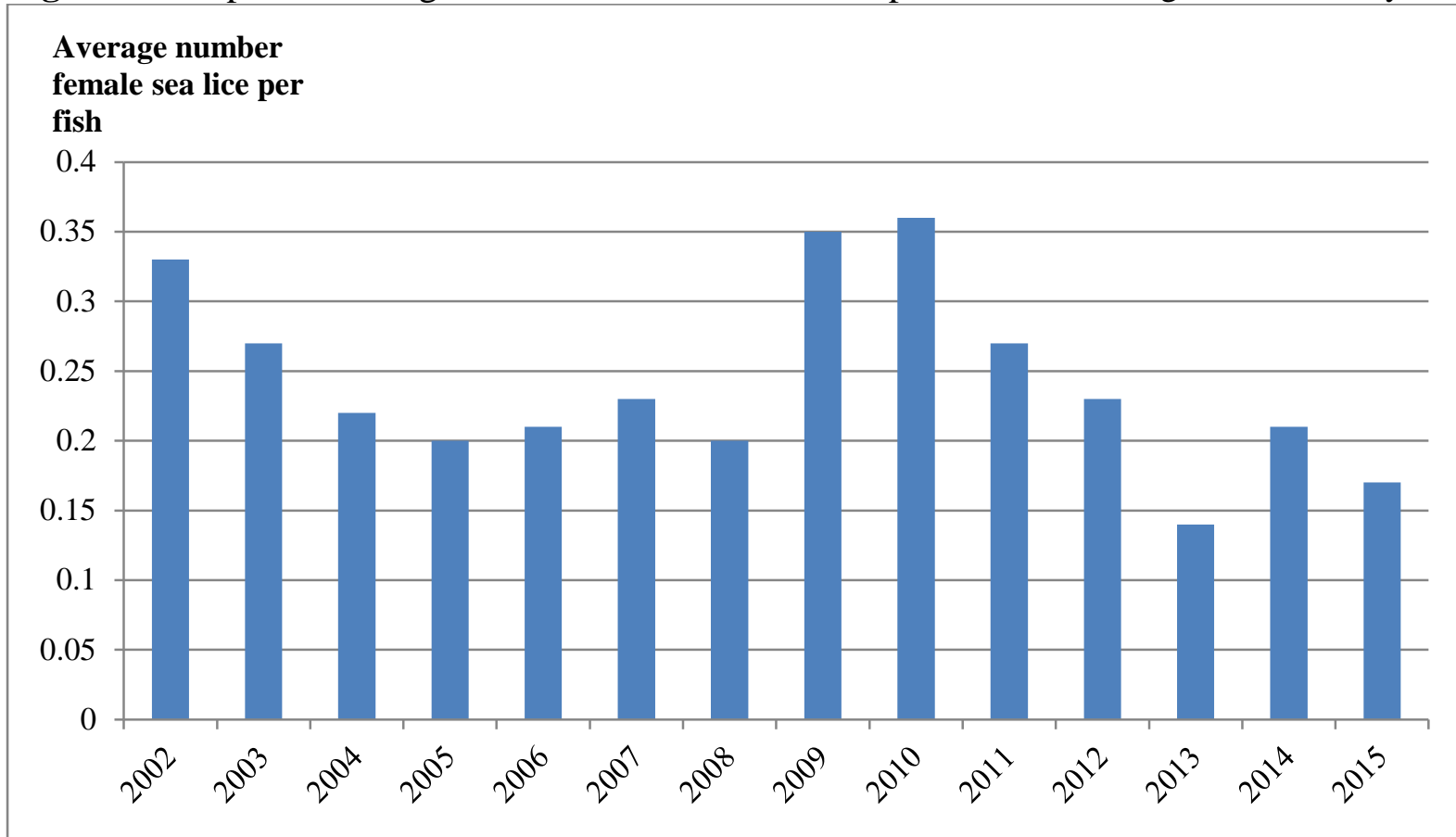

Source: plotted from data on mysalmon.no

\subsection{Important issues and success stories}

\subsubsection{Commitment by the salmon industry to non-chemical sea lice treatments}

The last five years have seen an unprecedented trend in investment by the major salmon producers in non-chemical management practices to ameliorate infestation levels by sea lice including:

- hydrolicing equipment which bathes fish in fresh water for short periods; 
- thermolicing whereby salmon are exposed for a brief period to water at a significantly elevated temperature (30 - 34 degrees). Both hydrolicing and thermolicing require dedicated well-boats with associated plant and operatives;

- the routine use of "cleaner fish"; and

- investment in RAS facilities for the production of large post-smolts allowing reduced culture time in marine cages, thereby reducing opportunities for sea lice infection.

\subsection{The way forward}

\subsubsection{Salmon farms}

The salmon farming industry cannot continue its so-far remarkable success without managing the sea lice problem. The successful cultivation of "cleaner fish" with desirable performance will take several years and some of the new non-chemical lice treatments and management practices will certainly prove successful whilst others will not. The optimisation of new culture systems - for example, fullyenclosed floating offshore systems - will also take time and it is likely that successful containment of the problem will require use of a combination of approaches. However, it is clear that the industry is committed to this path as hundreds of millions of dollars have been committed to these programmes.

\section{MARKETS AND TRADE}

\subsection{Status and trends}

\subsubsection{Production}

Trade statistics are complex ${ }^{15}$ and a full presentation of trade in aquaculture products in Europe is beyond the scope of this brief mid-term review. For a detailed recent overview of trade in European fishery and aquaculture products see (Borrello, Natale and Motova, 2014).

The production of fishery and aquaculture products in Europe ${ }^{16}$ in 2014 was 17245920 tonnes, representing 10.2 percent of the world's production - a slight decline from 12 percent in 2005. European fisheries and aquaculture production for the last 10 years (2005-2014) is shown in Figure 13. European annual capture fisheries production has stayed essentially flat for the last 10 years. In contrast, the relative contribution of aquaculture production to combined fishery and aquaculture production has steadily increased over the same period, from 13.7 percent to 18.5 percent, representing a CAGR for aquaculture in Europe of 3.4 percent and a CAGR for combined fisheries and aquaculture total of 0.37 percent.

The increase in European aquaculture production can be almost entirely attributed to the increase in farmed Atlantic salmon, mostly from the Kingdom of Norway.

\footnotetext{
${ }^{15}$ It is difficult to dis-aggregate aquaculture and fishery products in, for example in consumption data. There are significant intra-Europe trades, some of which are imports for processing and re-exporting both within and out with the region.

${ }^{16}$ Excluding, in this case, the Republic of Turkey, the State of Israel and the Republic of Cyprus.
} 
Figure 13. Trend in combined fisheries and aquaculture production in Europe

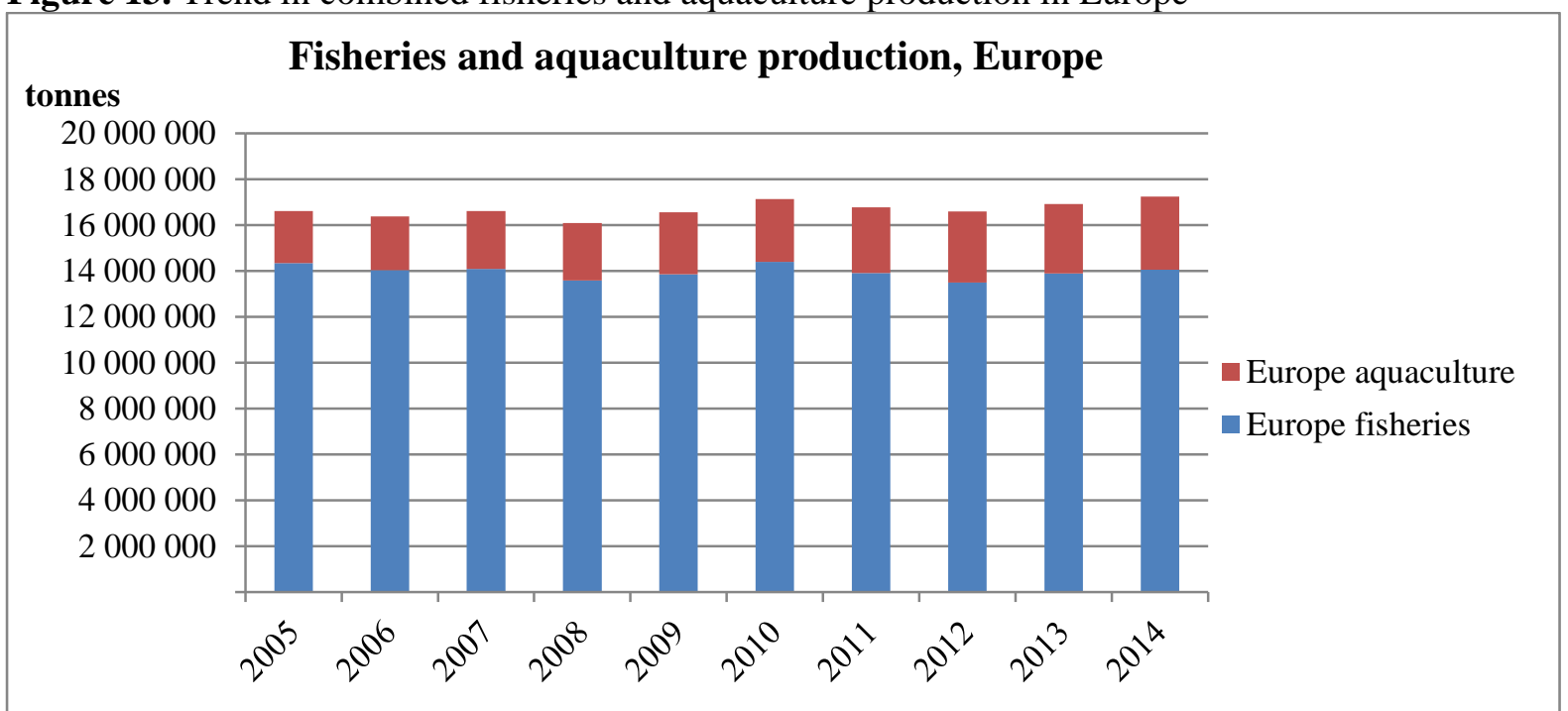

Source: FAO Fisheries Global Information System datasets.

\subsubsection{Consumption}

The net fish supply (catch, production and imports) to the European region has shown a small but steady increase of 3.74 percent over 10 years, slightly exceeding population growth in the region (2.86 percent) over the same period. Consequently the average consumption per capita in the region has increased slightly over the same period. However, the lack of homogeneity in diet across the region makes an average consumption figure irrelevant; the range within the region extends from one of the highest in the world (the Republic of Iceland, at over $90 \mathrm{~kg} /$ person/year) to around $5 \mathrm{~kg} /$ person/year (Hungary, the Republic of Serbia, the Republic of Albania).

Figure 14 shows that there is a tendency for eastern European countries to have the lowest per capita consumption of fish products, but no common trend exists for the change in consumption amongst the countries in the region.

Figure 14. European per capita consumption of fish and shellfish in 2007, 2011 and 2014

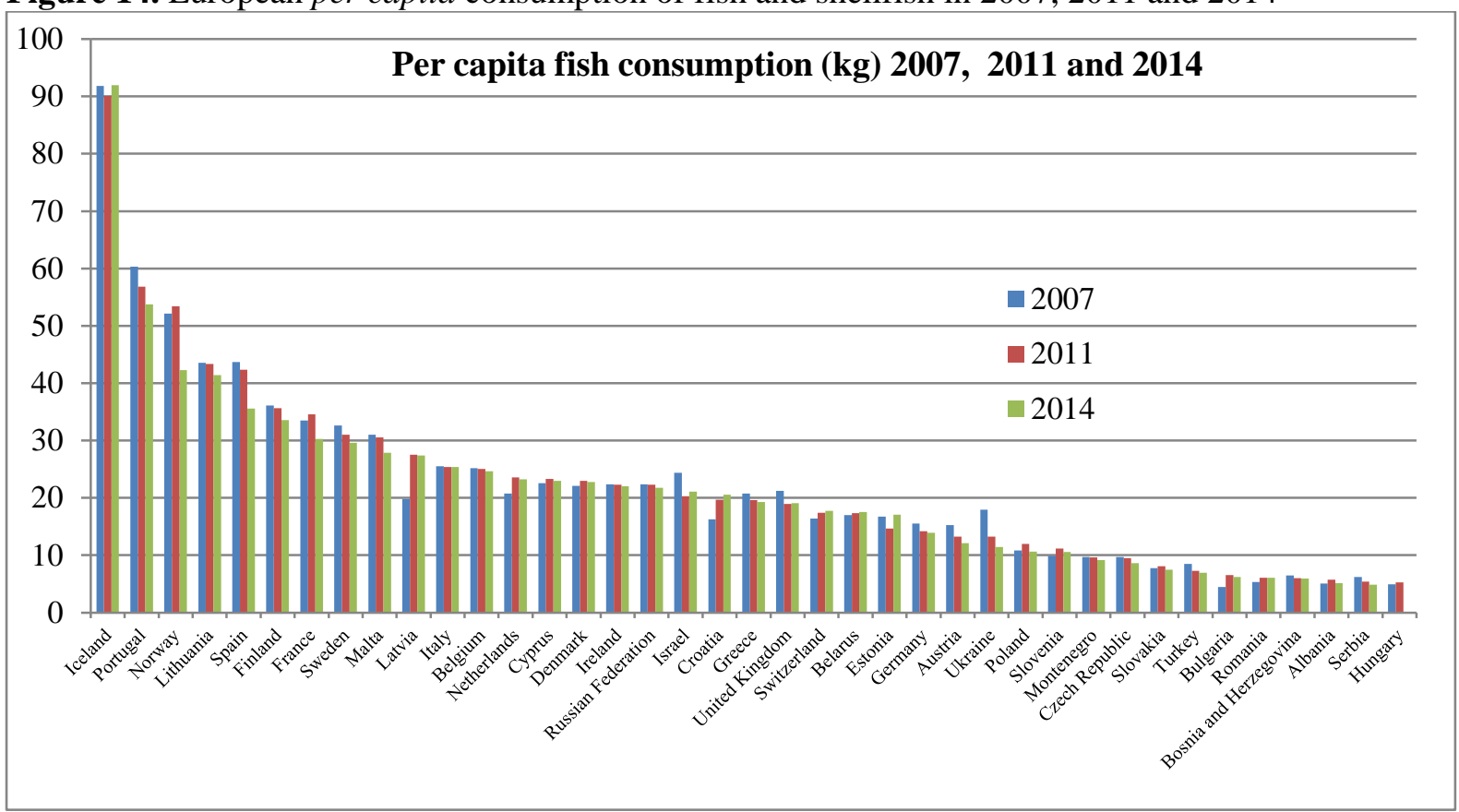

Source: FAO Fisheries Global Information System datasets. 


\subsubsection{Trade}

The balance of trade for Europe has been calculated from 2013 data as follows:

Figure 15. European trade flows in fish and shellfish

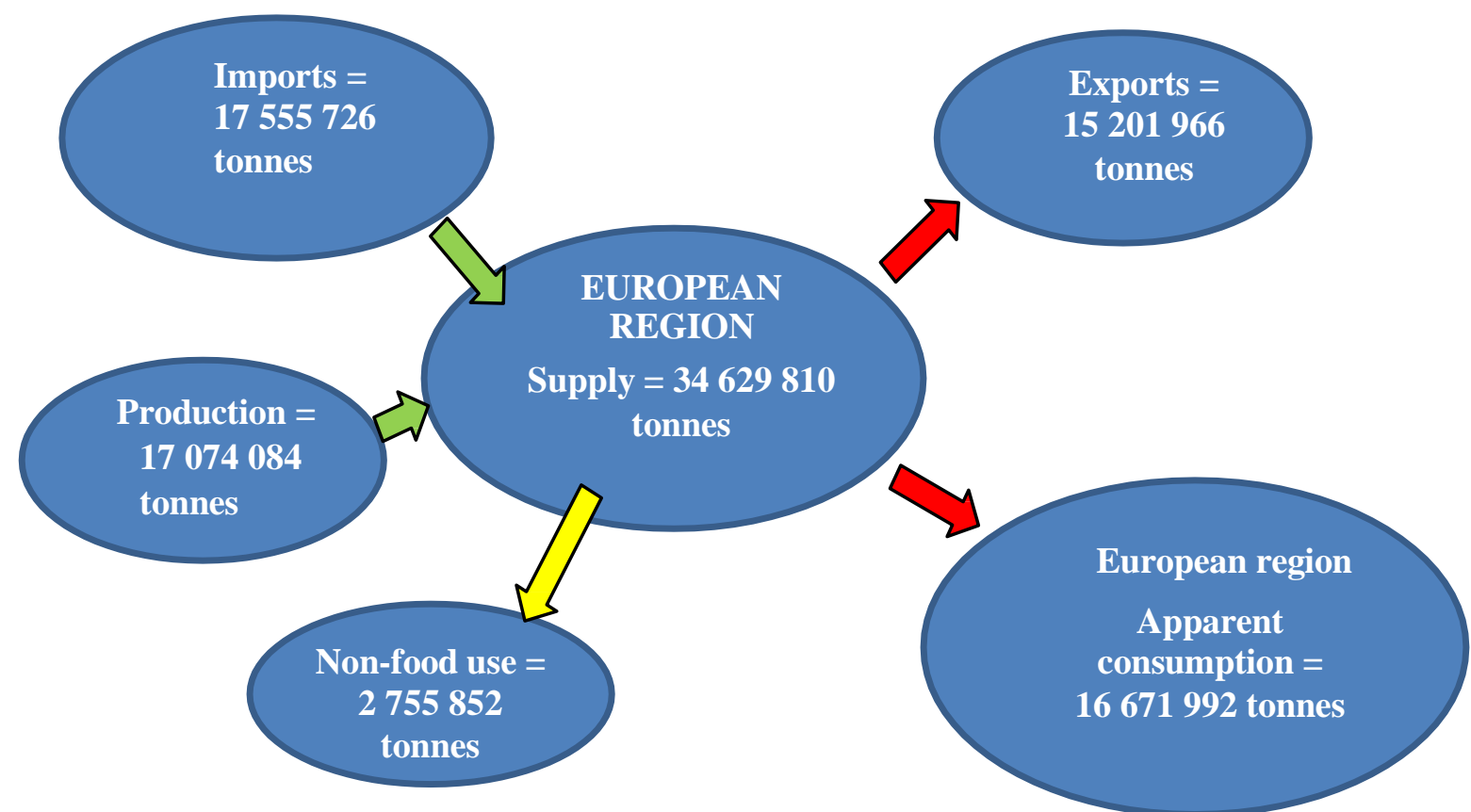

Source: calculated by the authors from FAO Fisheries Global Information System datasets for 2013.

The trade balance diagram suggests that, in simple terms, the European region is approaching selfsufficiency in terms of tonnage of fish products. More realistically, it must be considered that consumer tastes in this relatively affluent region mean that the consumption of fish by species is not intrinsically linked to the availability of local supply and that consumer demand drives some of the imported component. The complexities in the statistics caused by fish being exported from the region for processing, then being re-imported, also limit the conclusions that can be drawn from the model.

Table 4. Consumer preferences in EU28 countries

\begin{tabular}{l|r|r|r}
\hline $\begin{array}{c}\text { Main commercial } \\
\text { species }\end{array}$ & $\begin{array}{c}\text { Per capita } \\
\text { (kg) }\end{array}$ & \% wild & \% farmed \\
\hline Tuna (canned) & 2.02 & 100 & 0 \\
\hline Salmon & 1.97 & 7 & 93 \\
\hline Cod & 1.96 & 98 & 2 \\
\hline Pollack & 1.6 & 100 & 0 \\
\hline Herring & 1.52 & 100 & 0 \\
\hline Mussel & 1.27 & 12 & 88 \\
\hline Hake & 0.86 & 100 & 0 \\
\hline Pangasius & 0.82 & 0 & 100 \\
\hline Mackerel & 0.78 & 100 & 0 \\
\hline Squid & 0.76 & 100 & 0 \\
\hline Tropical shrimp & 0.68 & 42 & 58 \\
\hline Sardine & 0.54 & 100 & 0 \\
\hline Scallop & 0.48 & 81 & 19 \\
\hline Other & 9.41 & 77 & 23 \\
\hline Total & $\mathbf{2 3 . 8 7}$ & $\mathbf{7 6}$ & $\mathbf{2 4}$ \\
\hline Source: Borr & Nata
\end{tabular}

Consumer preferences in the EU28 countries - which account for about 70 percent of the consumption of fish and shellfish in the European region - are reported by Borrello, Natale and Motova (2014) in Table 4. Of the key farmed species, most salmon, mussels and scallops originate within the European region, whereas Pangasius and tropical shrimp represent imported aquaculture products. Canned tuna, the category of fish most consumed in the region, is almost exclusively fished and 92 percent of the world's tuna originates outside Europe (calculated by the authors from FAO Fisheries Global Information System datasets for 2010).

Source: Borrello, Natale and Motova, 2014. 


\subsection{Important issues and success stories}

\subsubsection{Analysis of international promotional campaigns}

A 2014 study (p.a.u. education, 2014) analyzed 85 campaigns in Europe and elsewhere in the world with the broad aim of promoting aquaculture products. The aim of the study was to evaluate the effectiveness of the campaigns and to infer best practice for future campaigns. The authors noted that:

- There is a general lack of consumer knowledge and understanding of aquaculture.

- Aquaculture is often presented as a unified sector. This can cause messages to be contradictory by not differentiating between the wide diversity of species and production methods (e.g., finfish vs mussels). The result may be that generic messages are not sufficiently unique to promote specific products.

- There are two general areas in campaigns for aquaculture promotion. One is directed at the specific product and one to increase the visibility of aquaculture in broader campaigns about seafood and fishing sustainability, healthy diets and responsible consumption.

The output from the study is a list of 20 messages designed specifically to promote aquaculture in Europe in three different situations:

- first, to raise awareness of European aquaculture and to promote the sector as a necessary and environmentally-friendly food production industry;

- second, for the commercial promotion of European aquaculture products; and

- third, to promote entrepreneurship and investment in sustainable European aquaculture.

\subsubsection{Non-government standards}

Another important aspect of marketing aquaculture products is the proliferation over the last 10 years of non-government certification standards by organizations such as MSC (Marine Stewardship Council), ASC (Aquaculture Stewardship Council), Global GAP (Good Agricultural Practices) and others. In general, these organisations certify aquaculture products that demonstrate compliance with prescribed standards covering laws and regulations, food safety, occupational health, safety and welfare, animal welfare and environmental and ecological protection. Some of the schemes cover several stages of the production chain (including feed production and processing), whilst others focus only on farming activities. Such schemes therefore involve a "chain of custody" to assure the integrity of the final product.

Almost all such systems of standards are non-governmental; many are applied trans-nationally. In Europe at least, the principal retail outlets such as supermarket chains have adopted such standards as mandatory for suppliers in order to underpin their own claims for sustainability and corporate responsibility, concepts which are becoming increasingly important due to pressure from nongovernmental environmental and social campaign organisations. The European Union's supra-state Strategic Guidelines for the Sustainable Development of European Union Aquaculture (European Commission, 2013) actually rely upon private standards operators. One of the four key objectives is "Promoting a level playing field for European Union operators by exploiting their competitive advantages", acknowledging that "voluntary certification schemes can play a role in this context".

The certification schemes can be business-to-business or business-to-consumer. The former are used to assure businesses within the value chain of the provenance of the product they are handling, whilst the latter are geared toward providing assurance to the final consumer via recognisable labels. There is some risk that the proliferation of such labels can lead to consumer confusion. However, there is increasing adoption of certification and labelling as both policy makers and food retailers in developed economies perceive it to be a useful tool for improving sector governance and overall standards. Between 2003 and 2015, certified sustainable seafood (both aquaculture and wild catch) 
grew from 0.5 to 14 percent of global production, reaching a retail value of US\$11.5 billion in 2015 (Potts et al., 2016).

\subsection{The way forward}

\subsubsection{Increase in European aquaculture products on the European market}

Although aquaculture production in Europe continues to rise (3.1 percent CAGR, 2011-2015) it still represents only a modest 19 percent of total fished and farmed fish and shellfish production in the region. Furthermore, European aquaculture is dominated by farmed Atlantic salmon and there is general agreement that salmon production in this sector is unlikely to continue rising at the current rate. During the necessary period of development and adoption of new technologies, growth in supplies of farmed Atlantic salmon products is likely to continue to rise but at a slower rate that in the last 5 years.

Mussel production continues to increase and there are encouraging early signs that the adoption of large-scale longline technologies using bulk mechanised handling and adopted from the New Zealand industry (see Section 3.1) could open up opportunities for large-scale expansion of the sector and produce the highest-quality (suspended culture) product at low production costs. Europe currently imports significant quantities of Chilean farmed mussels (Mytilus chilensis), implying opportunities to replace these imports with increased European production.

The other main sector of the European aquaculture sector showing significant growth is the cage production of European seabass and gilthead seabream. During the last few years, the consequences of the Eurozone crisis coupled with inertia in the site licence approval system (see Section 8) have greatly limited growth and investment in the industry in the Hellenic Republic - initially the leading country in the sector - but production in neighbouring the Republic of Turkey has continued to increase as the industry matures and production methodology becomes well-established. There is clear potential for expansion of production but that will require substantial capital investment and a receptive market, although it may take several years to realise the potential.

In recent years there has been an increasing trend in northern Europe for the main aquaculture products, especially salmon, trout and mussels, to be retailed in value-added, processed form. For example, salmon and trout are routinely offered by supermarkets as portion-sized or family mealsized fillets in controlled-atmosphere packaging containing an accompanying sauce. Similarly, cooked mussels in a sauce are commonly offered vacuum-packaged in the shell, requiring only brief re-heating rather than cleaning and cooking (Scott et al., 2010). It is clear that such convenient retail offerings, accompanied by promotional marketing campaigns as described in section 5.2.1, are widening access to aquaculture products and helping to grow the market sectors.

\subsubsection{Increase in competitiveness of aquaculture products}

In terms of improving competitiveness, several initiatives are underway. One key component is EUMOFA - the European Market Observatory for Fish and Aquaculture Products. The programme started as a pilot funded by the European Union (Member Organization) in 2007 as a market intelligence tool for the European Union fisheries and aquaculture sector. It aims to:

- increase market transparency and efficiency;

- analyse European Union markets dynamics; and

- support business decisions and policy-making.

In 2014, objectives were extended to include:

- increase the supply chain coverage and the number of countries involved in the data collection system;

- improve dissemination tools, providing also outlooks and market prospects; and

- analyse international context and trade flows. 
The aim is to improve both industry and policy makers' understanding of market demands and dynamics. This has now been supplemented by the Primefish (2015) project funded under Horizon 2020 to develop "an innovative market-orientated prediction toolbox" which will allow users to "strengthen the economic sustainability and competitiveness of European seafood in local and global markets". The Success project ${ }^{17}$ also contributes greater understanding of seafood value chain dynamics and competitiveness.

\section{CONTRIBUTION OF AQUACULTURE TO FOOD SECURITY AND SOCIAL AND ECONOMIC DEVELOPMENT}

\subsection{Status and trends}

\subsubsection{Regional economic development}

Aquaculture in Europe can be regarded as an agent of regional economic development, particularly in rural areas with fragile economies where growth in aquaculture can create or preserve jobs thereby adding value to remote communities and contributing to their social and economic viability. Numbers of personnel directly employed in the production process in the aquaculture sector in 2012 is shown in Table 5, based on data available for a range of countries in Europe.

Table 5 Employment in aquaculture in selected European countries

\begin{tabular}{|c|c|c|c|c|c|c|}
\hline & $\begin{array}{c}\text { No of } \\
\text { enterprises }\end{array}$ & $\begin{array}{c}\text { Total sales } \\
\text { (Thousand } \\
\text { tonnes) }\end{array}$ & Employment & $\begin{array}{c}\text { Full-time } \\
\text { equivalent } \\
\text { (FTE) jobs }\end{array}$ & $\begin{array}{c}\text { Production } \\
\text { per FTE }\end{array}$ & $\begin{array}{c}\text { Average Wage } \\
\text { (Thousand } \\
\text { US\$) }\end{array}$ \\
\hline Bulgaria & 163 & 2.5 & 454 & 321 & 7.8 & 3.9 \\
\hline Croatia & 174 & 12.7 & 1892 & 1464 & 8.7 & 22.0 \\
\hline Cyprus & 10 & 3.2 & 259 & 248 & 12.9 & 13.8 \\
\hline Denmark & 127 & 43.7 & 432 & 311 & 140.5 & 88.4 \\
\hline Estonia & 6 & 0.2 & 22 & 17 & 11.8 & 11.6 \\
\hline Finland & 120 & 11.1 & 402 & 326 & 34.0 & 47.6 \\
\hline France & 3249 & 268.7 & 18640 & 10581 & 25.4 & 29.6 \\
\hline Germany & 8 & 6.7 & 39 & 39 & 171.8 & 73.4 \\
\hline Greece & 1051 & 114.8 & 4900 & & & \\
\hline Ireland & 279 & 36.2 & 1,708 & 956 & 37.9 & 52.8 \\
\hline Italy & 587 & 191.2 & 5164 & 1937 & 98.7 & 46.4 \\
\hline Malta & 6 & 7.0 & 167 & 153 & 45.8 & 28.9 \\
\hline Netherlands & 115 & 43.5 & 467 & 332 & 131.0 & 41.4 \\
\hline Poland & 840 & 33.2 & 5583 & 4377 & 7.6 & 14.3 \\
\hline Portugal & 1443 & 10.2 & 2,572 & 2083 & 4.9 & 10.1 \\
\hline Romania & 420 & 10.0 & 2968 & 2523 & 4.0 & 2.9 \\
\hline Slovenia & 11 & 0.4 & 34 & 28 & 14.3 & 35.5 \\
\hline Spain & 3032 & 271.3 & 19892 & 5743 & 47.2 & 28.1 \\
\hline Sweden & 174 & 14.8 & 370 & 263 & 56.3 & 41.8 \\
\hline United Kingdom & 641 & 209.5 & 3231 & 2705 & 77.4 & 48.3 \\
\hline Norway & 1355 & 1332.0 & 5893 & 5068 & 262.8 & \\
\hline Turkey & & 212.8 & 8000 & & & \\
\hline Totals & 13811 & 2836 & 83089 & 39475 & & \\
\hline
\end{tabular}

Source: Data for EU Member States adapted from STECF, 2014a

Data for Norway, Norway Directorate of Fisheries statistics, available at:

www.fiskeridir.no/English/Aquaculture/Statistics/Total

Data for Turkey, Eurofish.dk 2016 country report

According to the Scientific, Technical and Economic Committee for Fisheries of the European Union (Member Organization) (STECF, 2014a), which considered only European Union Member States, the

\footnotetext{
${ }^{17}$ www.success-h2020.eu
} 
majority of the 15000 enterprises in the European Union aquaculture sector are micro-enterprises with fewer than 10 employees. In 2012 these comprised 90 percent of all aquaculture enterprises in the European Union (Member Organization) (by number of enterprises, rather than by production output). These micro-enterprises tend to be family owned and use extensive production methods and systems.

The calculation of production per Full Time Equivalent (FTE) reveals substantial differences depending upon the type of aquaculture and the scale of production. For example, the Kingdom of Spain has very high employment figures, reflecting mainly a high proportion of relatively small shellfish businesses, whereas the Kingdom of Norway demonstrates the efficiency of the salmon farming sector, which dominates production. In overall national economic terms, employment in the aquaculture sector is largely insignificant. However, that conclusion belies the impact that aquaculture has on rural economies where there may be few other employment opportunities. In rural United Kingdom of Great Britain and Northern Ireland (Scotland), the Hellenic Republic and the Kingdom of Norway large-scale aquaculture operations may be the largest local employer, injecting money into fragile local economies with the additional benefit of relative security of employment and the need for a range of skills from employees. Nor does efficiency imply a lack of growth opportunities. Total aquaculture employment in the Kingdom of Norway, for example, has increased significantly in the last 5 years (see Figure 16).

Figure 16. Production and employment trends in Norwegian aquaculture

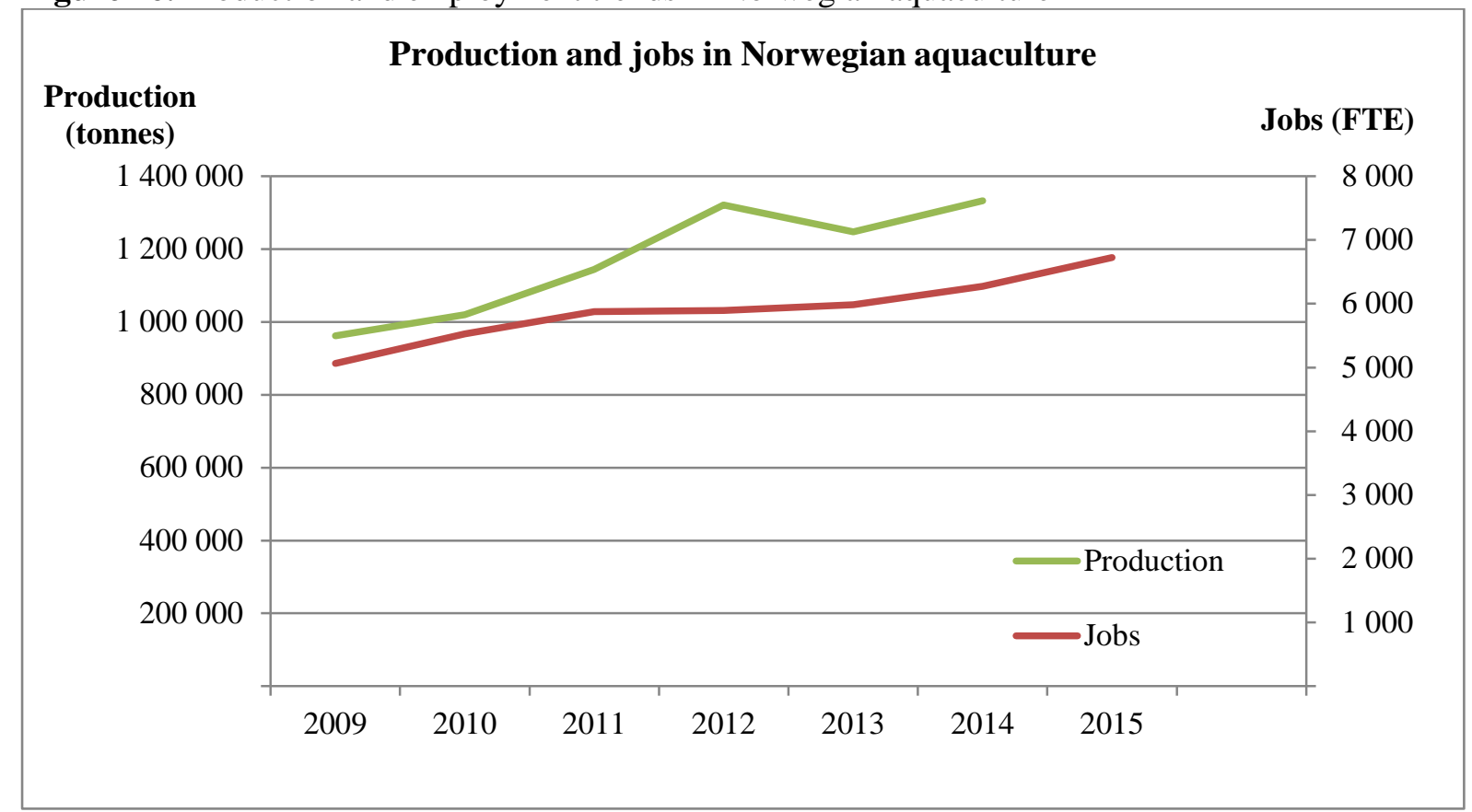

Source: www.fiskeridir.no/English/Aquaculture/Statistics/Total

\subsubsection{Food security; feeding fish to fish; dependence upon capture fisheries}

A key concern about the development of aquaculture is the necessity when producing carnivorous and omnivorous fish - which in Europe represent the largest sector (Atlantic salmon) and the faster growing segments (Atlantic seabass and gilthead sea bream) - of using fish meal and fish oils ingredients to produce diets. As noted by the high-level panel of experts on food security and nutrition (HLPE, 2014), from a food security and nutrition perspective, debate continues on whether it would be preferable to use such fish directly for human consumption rather than for fishmeal, especially as 'lower grade' but nutritious fish could be consumed by food-insecure people.

Fish feed manufacturers are clearly not only aware of the importance of the debate in the context of global food security but also conscious of their own industry's being dependent upon a variable 
resource from fisheries outside their control. Consequently, considerable research and development has been carried out on the substitution of marine proteins and oils with those from other sources. Ytrestøyl, Aas and Åsgård (2015) report on the continuing reduction in these components over recent years, as shown in Figure 17.

Figure 17. Nutrient sources in Atlantic salmon diets, shown as a percentage of the total feed

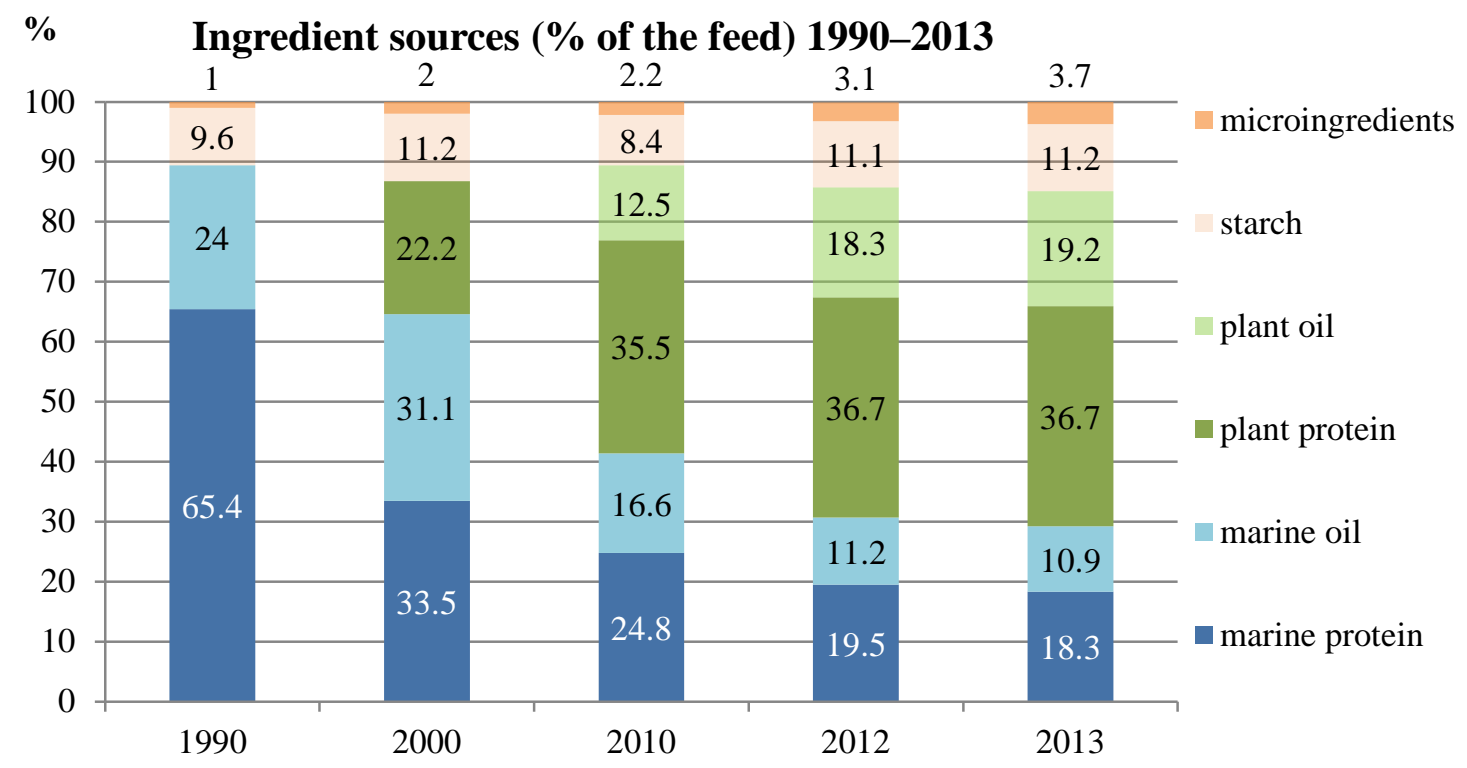

Source: Ytrestøyl, Aas and Åsgård, 2015.

\subsection{Important issues and success stories}

\subsubsection{Since 2010, farmed salmon have been net producers of marine protein and marine oil}

Ytrestøyl, Aas and Åsgård (2015) conclude that, since 2010, farmed Atlantic salmon can be regarded as net producers of marine proteins and marine oils. As can be seen from Figure 18, the ratios have been dropping since 1990.

Figure 18. Trend in dependency of farmed salmon diets on marine protein and marine oil

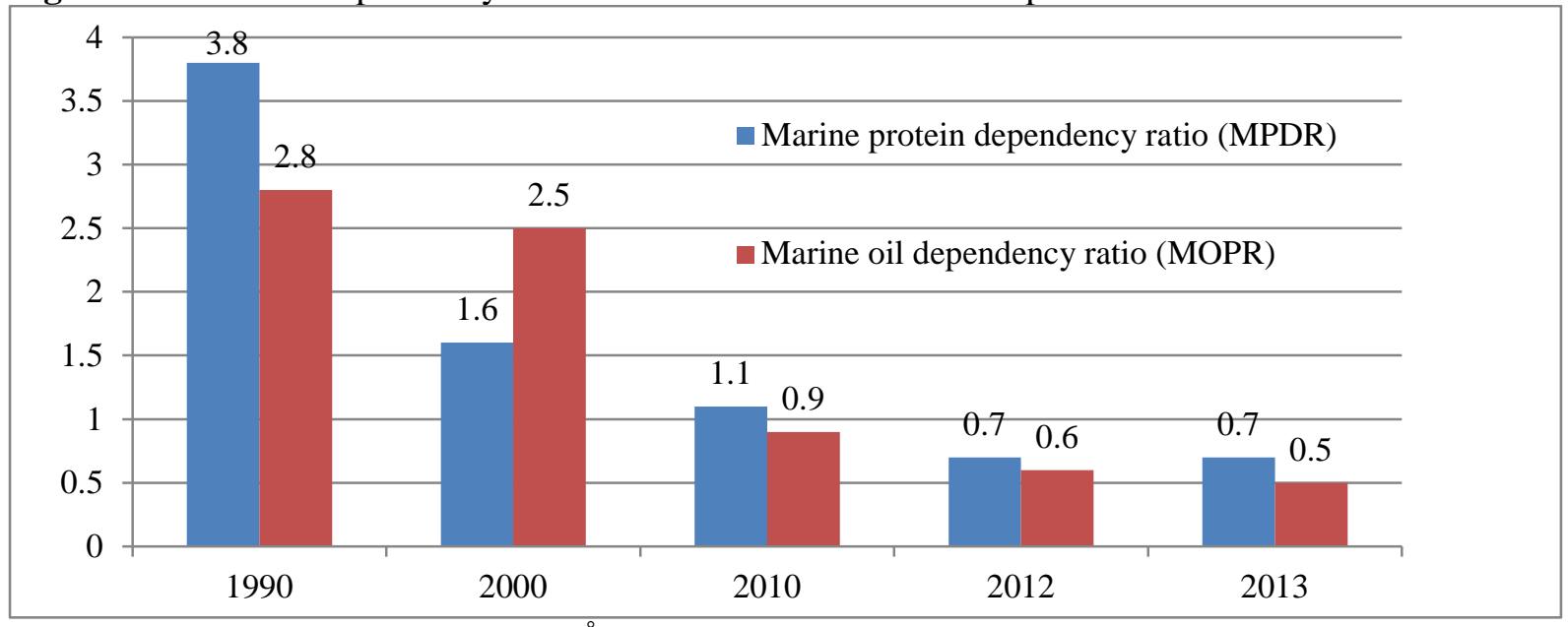

Source: adapted from Ytrestøyl, Aas and Åsgård, 2015. 


\subsubsection{Traditional carp farming prospects}

Traditional extensive carp production in large ponds and waterways in Eastern Europe - mainly in the Russian Federation, Ukraine, the Republic of Poland, Hungary, the Czech Republic and the Federal Republic of Germany - represents more than just a significant supply of fish (238 000 tonnes in 2014, the third most-produced finfish in Europe). The traditional pond systems and waterways, the design and original construction of which in many cases dates back hundreds of years, also represent managed landscapes with the ponds being crucial components for biodiversity conservation (Seiche, 2012). The continuation of this sector of aquaculture also has strong social, cultural and ecosystem benefit (Stündl et al., 2014) and provides employment in rural areas (Váradi, 2011).

Yet the financial viability of these production systems is fragile. Production from the European Union countries has remained static for the last 10 years (analysis of data from FAO, 201b) and the market for carp is slowly declining (Stündl et al., 2014). For pond systems in some European Union member states, financial assistance has been made available for maintenance of ponds, compensation for predator losses and promotion of aquaculture production methods that help to protect and improve the environment and conserve nature. However, as noted by Seiche et al. (2012), such measures are only a tool for short-term relief, not a solution. Strong strategic consideration and investment are needed if this important aquaculture sector is to continue.

\subsubsection{Aquaculture in coastal lagoons}

Aquaculture in coastal lagoons also continues to play a significant economic and social role for certain rural riparian communities. Across the European Mediterranean region there are about 400 lagoons covering a surface of over 640000 hectares where in several parts traditional aquaculture systems are carried out, notably "vallicultura" in the Republic of Italy and "aquaculture de esteros" in the Kingdom of Spain but also in other countries such the Republic of Albania, the Hellenic Republic and the Republic of Turkey among others. Extensive aquaculture and capture fisheries have contributed for centuries to preserving these productive ecosystems along and the ecological services provided by these environments whose integrity is at risk due to several threats (Cataudella, Crosetti and Massa, 2015).

\subsection{The way forward}

\subsubsection{A genetically modified plant oil is shown to be an effective substitute for fish oil as a source of eicosapentaenoic acid in salmon diets}

For both humans and farmed salmon there is a nutritional need for the omega-3 (n-3) long-chain polyunsaturated fatty acids (LC-PUFAs) docosapentaenoic acid (DHA) and eicosapentaenoic acid (EPA). These are found only in oily fish. One of the principal questions about the sustainability of modern salmon farming is its dependence upon fish oil in the feed. Continuing to source these LCPUFAs from fish oil is widely regarded as unsustainable. Various alternative sources of oils including algae and plants have been investigated as alternatives.

A range of plant oils has been progressively substituted for marine oils in salmon feed over the last 10 years (see Section 6.1) thereby reducing the practice of feeding fish to fish. One of many candidate sources is the oilseed brassica, Camelina sativa, favoured for high alpha-linoleic acid content in the oil ( 30 percent) and low omega-6 content. Hixson, Parrish and Anderson (2014) investigated the use of Camelina oil as a partial replacement for marine oils in the diets of farmed salmon, with positive indications (reported in an on-line publication feednavigator.com). However, despite the use of a wide range of alternative sources, the resulting levels of LC-PUFAs from plant sources have been low.

Although the content of marine oils in commercial salmon feeds is now about one third of that used 15 years ago, the continuing expansion of the salmon sector still demands high quantities of oils derived from fish. A very recent breakthrough reported by Betancor et al. (2015) was the metabolic 
engineering of oilseed crops to synthesize n-3 LC-PUFA in seeds. Transgenic Camelina sativa expressing algal genes was used to produce an oil containing n-3 LC-PUFA to replace fish oil in salmon feeds. An analysis of fatty acid composition of the oil extracted from the seeds of transgenic Camelina showed accumulation of significant levels of EPA as high as those found in many fish oils ( $>20$ percent). Feeding studies showed that growth performance, feed efficiency, fish health and nutritional quality in terms of EPA + DHA for the human consumer were all unaffected by replacing fish oil with the genetically modified seed oil, suggesting potential for its use as an alternative source.

\section{EXTERNAL PRESSURES ON THE SECTOR}

Potential pressures considered in this section include direct and indirect consequences of climate change, disease outbreaks of epidemic proportions and ecological changes not attributable to climate change. Political pressures on the sector within Europe are considered in Section 8.

\subsection{Status and Trends}

\subsubsection{Direct and indirect consequences of climate change}

Climate change will have a progressive effect upon the European region with implications for the future of aquaculture in the region. The climate change effects are predicted to include:

- rising average air and water temperatures;

- longer periods of warmer summer temperatures;

- increased acidification of marine waters;

- sea level rise; and

- increased number and severity of storms (higher frequency of strong winds).

The direct consequences for marine aquaculture will include changes to the periods in which temperature conditions are suitable for successful culture. For the salmon industry in northern Europe, a $1-2{ }^{\circ} \mathrm{C}$ rise and any lengthening of the summer period would increase the time when optimal temperatures are experienced. However, a temperature increase of this magnitude would push Ireland and the Kingdom of Norway's peak summer temperatures closer to undesirably high temperatures, leading to higher oxygen demand, feeding stress and the potential for greater disease proliferation.

The survivable temperature range for the European seabass and gilthead seabream is around $5-28^{\circ} \mathrm{C}$ so the Mediterranean marine industry would face similar changes. However, as bass and bream production systems tend to follow developments in the salmon industry, larger, deeper cages located further offshore will offer lower, safer temperatures within cages.

Greater uncertainty exists around the secondary effects of temperature increases on marine aquaculture. Gubbins, Bricknell and Service (2013) have described the possible consequences as follows:

- Fish and shellfish disease organisms will be affected by a changing temperature regime but in an unpredictable manner. Sea lice will remain a problem in the salmon industry and under prolonged summer conditions may increase their infective pressure. Warmer conditions may result in the introduction of (presently) exotic diseases.

- Increased storminess will increase the potential for equipment failure and escapes.

- Ocean acidification is likely to have a detrimental effect for operations reliant upon natural mollusc spatfall.

- Warmer waters and calmer, drier summer months will affect planktonic communities though specific detail is difficult to predict. There may be an increase in the frequency of jellyfish blooms and toxic algal blooms. 
Some inland freshwater aquaculture production systems may be more susceptible to temperature rises than are marine systems. Whilst traditional extensive carp culture will benefit from the low stocking densities and semi-natural culture environments (which may offer cooler volumes of water within systems), intensive trout production will, in some circumstances, experience difficulties. In parts of central and Eastern Europe, much trout aquaculture makes use of floating cages in relatively shallow lakes and reservoirs; in such situations, higher summer temperatures and potentially reduced depth from greater evaporation are likely to be problematic. Similarly, flow-through trout systems in some locations will experience much lower water availability in warmer summer months.

\subsubsection{Disease outbreaks of epidemic proportions}

The European aquaculture industry has experienced many disease epidemics. Notable examples include oyster herpes virus, infectious salmon anaemia and the Gyrodactylus salaris parasite. Prevention of such outbreaks could be effected through national (or areal, depending on the aetiology) surveillance and monitoring programmes and the collection and analysis of long-term epidemiological data that attempt to correlate the occurrence of symptoms with external factors. Turnbull et al. (2011) summarise the application of epidemiology to aquaculture. They also note that the EU-funded project Benefish ${ }^{18}$ examined 49 existing data sets relating to the health, welfare and production of farmed fish, to identify potential interventions to improve fish welfare. Out of the 49 datasets only eight possible interventions were identified.

Control of the spread of such diseases requires that agreed national or regional procedures are in place and well-managed.

\subsubsection{Ecological changes not attributable to climate change}

Algal blooms or jellyfish blooms can occur independently of general climate forcing. As with disease outbreaks, monitoring of early signs and planning and rehearsing procedures to minimise the consequences to the industry are the main agents of prevention.

\subsection{Important issues and success stories}

\subsubsection{Epidemiology and monitoring for early indications of disease presence}

Soares et al. (2012) described use of the receiver operating characteristic (ROC) approach on mortality data from production cycles of marine Atlantic salmon belonging to a single company. They found that for fish under $750 \mathrm{~g}$ abnormal rates of mortality did not provide a strong indication of the presence of disease. However, abnormal levels of mortality for fish weight over $750 \mathrm{~g}$ provided a strong indication of the presence of disease with the exception of both suspected and confirmed IPN.

\subsubsection{Disease surveillance and action planning}

In response to the consequences in the Kingdom of Norway of the spread of Gyrodactylus salaris, the Scottish Government has established a surveillance programme (Marine Scotland, 2013). It has funded research and development and developed a real-time polymerase chain reaction (PCR) assay that reduces screening times by at least five-fold compared to previous methods. It also has a detailed contingency plan in place (Scottish Government, 2011).

\subsubsection{Technologies and programmes for national or regional monitoring of the marine environment}

In the United Kingdom of Great Britain and Northern Ireland, the Centre for Environment, Fisheries and Aquaculture Science (CEFAS) has a set of "SmartBuoys" positioned at strategic locations around

\footnotetext{
${ }^{18}$ www.benefish.eu
} 
the coast. They are autonomous systems of moored, automated, multi-parameter recording platforms used to collect marine environmental data. The data they collect can provide or facilitate:

- evidence used for eutrophication assessments;

- improved understanding of environmental variability;

- new insights into ecosystem function;

- monitoring change in marine biodiversity;

- improved model validation and testing;

- confirming satellite imagery of the sea ("ground-truthing").

CEFAS also maintain a system called WaveNet, a strategic wave monitoring network for the United Kingdom of Great Britain and Northern Ireland that provides a single source of real-time wave data from a network of wave buoys located in areas at risk from flooding. Strategic and co-ordinated development of such networks across the European region could provide a dedicated monitoring service of long-term value to the aquaculture industry.

\subsection{The way forward}

\subsubsection{Increasing use of systems protected from environmental changes and events}

The use of RAS - introduced in Section 4 as a way of minimizing aquaculture's impact on the environment - is also an example of reducing the potential impact of environmental change on the aquaculture industry. The experience gained from the current rapid development of highly sophisticated RAS systems for salmon smolts and post-smolts will give valuable insight into the opportunity for future application to other species.

\subsubsection{Future-proof system design}

Anticipation of future potential environmental conditions such a more storms and more frequent higher waves should be a consideration in designing new equipment. The current consideration of moving cage farming further offshore, described in Section 4, provides opportunities for designing for more extreme conditions and incorporating remote structural monitoring capability.

\section{GOVERNANCE AND MANAGEMENT OF THE SECTOR}

\subsection{Status and trends}

\subsubsection{Strategic planning in Europe by national and supra-national bodies}

The FAO Sub-Committee on Aquaculture (COFI-SCA) has recently produced a summary paper ${ }^{19}$ (COFI:AQ/VII/2015/5) of regional strategic frameworks or plans for aquaculture. The European review took account of 94 relevant documents and carried out a comprehensive analysis, the detailed outcomes of which are beyond the scope of this document.

The key findings included an analysis of the priority areas identified in all strategic planning documents. Unsurprisingly, they found that the four priorities highlighted in the EC strategic guidelines (EC, 2013) consistently appeared as priorities in the individual strategic plans. They were:

- Simplification of administrative procedures (highlighted in 18 documents)

- Securing sustainable development and growth of aquaculture through coordinated spatial planning (highlighted in 18 documents)

\footnotetext{
${ }^{19}$ For complementary views on aquaculture in the Region, please see the Report from the COFI Sub-Committee on Aquaculture, Brasilia, Brazil, 3-9 October 2015, available at the following link: www.fao.org/cofi/4334104a74a5d167de0034251e8eaf83de443e.pdf
} 
- Enhancing the competitiveness of European Union aquaculture (highlighted in 17 documents)

- Promoting a level playing field for European Union operators by exploiting their competitive advantages (highlighted in 14 documents)

Additional top priority areas highlighted across all the documents considered were:

- Fish health and welfare (highlighted in 15 documents)

- Prioritization for development (highlighted in 13 documents)

- Regulation and environment (highlighted in 13 documents)

- Public perception (highlighted in 13 documents)

- Licensing (highlighted in 12 documents)

- Technology for innovation (highlighted in 12 documents)

- Knowledge transfer between research and industry (highlighted in 12 documents)

- Sustainable strategies (highlighted in 12 documents)

The report ${ }^{20}$ also noted that the Kingdom of Norway did not have any issues or priority listed as "Strategic" and Russian and Ukrainian documentation focused on "Competitiveness" and the creation of favourable conditions for producers.

The strategic plan of the Russian Federation (Russian Federation, 2014) aims to support the development of mariculture - in particular an increase in shellfish production - and the reinforcement of the freshwater farming sector, in particular the production of sturgeon. The aim is to treble aquaculture production by 2020 (from 2012 levels).

According to Hersoug (2015), the Norwegian Government continues in its strategic objective that the Kingdom of Norway should become the world's leading seafood nation. Its strategic plan includes the specific objective to grow the salmon sector on the basis of economic and environmental sustainability to three times its present size by 2030 and five times by 2050 .

\subsubsection{Regulatory and administrative structures}

With the notable exceptions of the major European aquaculture producers the Kingdom of Norway, the Russian Federation and the Republic of Turkey, the shaping of regulations and the instruments for the development of and investment in most of the aquaculture sector in Europe falls under the aegis of the European Union (Member Organization). The principal regulatory and support frameworks for aquaculture in the European Union (Member Organization) since the early 1970s have come from the Common Fisheries Policy (CFP) in which aquaculture was initially included, primarily because its products entered the same markets as those from the European Union's capture fishery. In 2014, the CFP underwent substantial reform, recognising that aquaculture falls within the CFP in its own right, alongside capture fishery and fish processing sectors.

The evolution of the CFP has left some anomalies. As pointed out by Bostock et al. (2016), in the context of capture fisheries, the CFP is the primary instrument for the management of wild fish stocks for the common good, whereas aquaculture is a commercial activity where fish or shellfish stocks belong to the owners of aquaculture companies.

The obstacles to obtaining permissions for a new aquaculture site within the European Union (Member Organization) have been highlighted as a particular problem. Hedley and Huntington (European Parliament, 2009) note that the typical time for new companies in various Member States to achieve licences and compares these with the average time in the Kingdom of Norway (6 months) as follows: the Republic of Croatia 12 months; the Kingdom of Spain, the French Republic and the Republic of Cyprus 18 months; the Republic of the Republic of Slovenia, the Republic of Italy and the Hellenic Republic 24 months. The target license processing time for new companies, to be

\footnotetext{
${ }^{20}$ Report from the COFI Sub-Committee on Aquaculture, Brasilia, Brazil, 3-9 October 2015, available at the following link: www.fao.org/cofi/43341-04a74a5d167de0034251e8eaf83de443e.pdf
} 
achieved by 2020, is 3 months. Hedley and Huntington (European Parliament, 2009) found that new applications in the Hellenic Republic required various ministries to consider 85 laws, 23 legal advices and 70 legal interpretations. Associated problems include "a lack of coordination among the different bodies involved, overlapping competences, different approach-concept concerning common issues and the lack of demarcation zones for the various activities". However, this complexity is partly the result of multiple management criteria particularly in the marine coastal zone. For instance, Jackson (2013) lists 19 European Union directives and regulations to be considered in the establishment and management of aquaculture enterprises (in addition to common business and trading regulations).

\subsubsection{Allocation of zones for aquaculture}

In terms of facilitation of access to water and space, the General Fisheries Commission for the Mediterranean (GFCM) ${ }^{21}$, a regional fisheries management organisation with a specific mandate also for aquaculture in the Mediterranean and the Black Sea, adopted a specific resolution on allocated zones for aquaculture (AZA) in 2012 (FAO, 2012). From a marine spatial planning perspective, the definition of AZAs is considered an effective management tool to increase the available space for aquaculture development in the coastal zone under an agreed level of environmental change (SanchezJerez et al., 2016). Many countries in Europe and in the GFCM area of application are taking up the AZA resolution and adapting this within their national legislations. The GFCM is also preparing a "Strategy for the sustainable development of Mediterranean and Black Sea aquaculture" in which AZA and the governance of aquaculture figure prominently (FAO, 2016c).

Increased competitiveness is expected to be stimulated through the promotion of $R \& D$, innovation and business differentiation, as well as through the exploitation of potential business opportunities such as integration with angling and tourism or offshore wind farms or the valorisation of environmental services (e.g. extensive ponds and habitat conservation). A role is also envisaged for stronger producers' organisations.

Exploiting competitive advantage involves building on the reputation of European products for environmental protection, health and consumer protection, informing consumers better through food labels and information campaigns, and exploiting niche markets through certification schemes such as organic aquaculture.

\subsubsection{Financial support for development}

Since 1994, the European Union aquaculture sector has been supported with research and development funds from the European Union (Member Organization) under its Framework funding system. The latest manifestation of these funds (Horizon, 2020) allocates $€ 4.15$ billion for the period 2014-2020 for all food security strategic research and development, which includes aquaculture projects under the theme headings of food security, sustainable agriculture and forestry, marine, maritime and inland water research and the bioeconomy. The aquaculture priorities within the theme are drawn from the Strategic Guidelines (EC, 2013): they include domestication of new species, interactions with the environment, health and nutrition of farmed aquatic organisms, reproduction and breeding and social aspects of the seafood sector for social cohesion in coastal areas. It is important to note that the Kingdom of Norway, the Republic of Turkey and several other non-EU countries can participate fully in Horizon 2020 projects.

In addition to research and development funding, the European Union (Member Organization) also makes capital grants from the Structural and Investment Funds through the European Maritime and

\footnotetext{
${ }^{21}$ GFCM Contracting Parties include the Republic of Albania, the People’s Democratic Republic of Algeria, the Republic of Bulgaria, the Republic of Croatia, the Republic of Cyprus, the Arab Republic of Egypt, European Union, the French Republic, the Hellenic Republic, the State of Israel, the Republic of Italy, Japan, the Lebanese Republic, Libya, the Republic of Malta, the Principality of Monaco, Montenegro, the Kingdom of Morocco, Romania, the Republic of Slovenia, the Kingdom of Spain, Syrian Arab Republic, the Republic of Tunisia and the Republic of Turkey. Ukraine, Georgia and Bosnia Herzegovina are Cooperating Non-Contracting Parties whilst the Russian Federation is a Non-Contracting Party.
} 
Fisheries Fund (EMFF). The EMFF is the financial instrument that will foster the implementation of the reformed CFP (Regulation (EU) No 508/2014) for commercial ventures which target the achievement of national strategic objectives and are used in conjunction with additional capital cofunding provided by each member state. Each country is required to draw up an operational programme that takes into account both the European Union fisheries and aquaculture policies and national policies and priorities (in the case of aquaculture, expressed through a Multiannual National Aquaculture Plan). Applicants are required to show compliance with the relevant national operational programme.

The various financial instruments for such investment since 1994 have been: the Financial Instrument for Fisheries Guidance (FIFG), which for the period 2000-2006 provided €317 million towards investment funds of €1.2 billion, and the European Fisheries Fund 2007-2011, which allocated $€ 1.24$ billion to aquaculture investments. The present EMFF runs from 2014 to 2020 and has a total European Commission budget of €6.4 billion.

\subsubsection{Voluntary standards and sector governance}

A well-identified trend is the increasing strength of multiple retailers (supermarkets) as the primary channel linking food producers and consumers. Recognizing supermarkets' role as "choice editors" for consumers, environmental and other lobby groups have applied pressure to these retailers to be accountable for the provenance, safety and environmental and ethical credentials of the products they sell. This in turn has stimulated industry to develop suitable standards and codes of practice, often in partnership with lobby groups and other stakeholders that can be certified by third parties. These voluntary standards generally supplement and complement statutory requirements. Whilst this increased self-governance of the value chain is generally perceived as positive by Western consumers and policy makers, there is concern for the power this gives to major companies and international lobby groups, potentially at the expense of smaller businesses and smallholders who are unable to afford the cost of compliance and hence lose access to markets (Thorstensen, Weissinger and Sun, 2015; Vandergeest and Unno, 2012). Nevertheless, Bush et al. (2013) argue that as one of a range of tools, voluntary standards can play a role in improved environmental and social governance.

\subsection{Important issues and success stories}

\subsubsection{Establishment of Norwegian "Green licences"}

The Norwegian government has decided that the environmental footprint of salmon farming will dictate official consent for future growth. It has moved from a position of "no more allowable biomass in marine cage farms" to one where companies within designated zones are rewarded for effective environmental controls by receiving increased biomass allocations. Initially, criteria included several variables including escapee numbers, lice infestation numbers on wild fish and the spread of organic matter or pathogens throughout the zone, but the pilot proposal was regarded as too complex and insufficiently objective. It is now based solely upon lice numbers.

In 2013, the Norwegian government also announced that 45 new production licences for Atlantic salmon and rainbow trout sites would be made available to operators who proposed and implemented novel solutions to the challenges of sea lice infestation and escapees. In 2015, the government announced further "green licences" for companies that develop and apply new technology designed to reduce the environmental footprint of production. This development has reportedly met with an exceptional response from the main production companies (Hjul, 2016). According to the trade publication Undercurrent News (Ramsden, 2016), Marine Harvest is evaluating four novel offshore technologies and will select one for commercial exploitation. At least four of the other major producers are making substantial investments in offshore system evaluation; so far only one, SalMar, has had its bid officially granted by the authorities. 


\subsection{The way forward}

The European Union funding instruments described in 8.1.4 are comprehensively tailored to stimulate research, innovation and commercial investment based upon identified barriers and clear strategic objectives. However, it is also appreciated that the success of these initiatives is dependent on stakeholder "buy-in" and cooperation. For instance research is more likely to result in innovations in production if the production sector is engaged in identifying research needs, investing in research and piloting new solutions. Stakeholder dialogue is seen as essential for solving conflicts over resource use (e.g. in coastal zone management) and driving innovative solutions that benefit all concerned (such as multi-use offshore platforms). Such dialogue should also involve the public, both as consumers and wider stakeholders in the natural environment (Kaiser and Stead, 2002). The positioning of aquaculture within the wider EC strategy for Blue Growth places an expectation for interdisciplinary and multi-sector cooperation.

In 2004 the European Union (Member Organization) proposed Technology Platforms (ETPs) as "industry-led stakeholder fora recognised by the European Commission as key actors in driving innovation, knowledge transfer and European competitiveness". The European aquaculture sector responded with the creation of the European Aquaculture Technology and Innovation Platform (EATiP), which was registered as a legal entity in 2009 and subsequently formally recognised as an ETP. In the following years it brought industry and research communities together to prepare a Strategic Research and Innovation Agenda (SRIA) with meeting and management supported through the European Union $7^{\text {th }}$ Framework RTD funding. This was published in 2012 and has been used to inform the European Union (Member Organization) of research priorities and guide strategic decision making in other organisations. For many organisations however, national and local funding and collaborative actions are more relevant, which has led to the establishment of several "mirror platforms" - national or regional multi-stakeholder organisations for aquaculture innovation and commercial development which can further coordinate and find representation at the European level through EATiP. These are currently:

- HATIP - Hellenic Aquaculture Technology and Innovation Platform (the Hellenic Republic)

- Platform for Fish Farming Technology Development in Hungary (Hungary)

- PTEPA - Spanish Fisheries and Aquaculture Technology Platform (the Kingdom of Spain)

- TECNOPEIXE - Galician Technological Fisheries Platform (the Kingdom of Spain)

- $\quad$ KNAQ - The Competence Network Aquaculture (the Federal Republic of Germany)

- Norwegian Centres of Expertise (NCE) Aquatech Cluster (the Kingdom of Norway Trondheim area)

Similar initiatives include:

- Norwegian Centres of Expertise (NCE) Aquaculture Cluster (the Kingdom of Norway Nordland Coast)

- akvARENA (the Kingdom of Norway)

- Aquacircle (the Kingdom of Denmark)

- $\quad$ East Regional Aquaculture Centre (ERAC/VCO) (the Kingdom of Sweden)

- Pôle Aquimer (the French Republic)

- Inagro (the Kingdom of Belgium)

Multi-stakeholder approaches are also important for the Scottish Aquaculture Innovation Centre (SAIC) (United Kingdom of Great Britain and Northern Ireland), Bord Iascaigh Mhara (BIM) (Ireland) and the Network of Aquaculture Centres in Central-Eastern Europe (NACEE).

The European Commission itself is taking the initiative with public engagement through the "Farmed in the European Union (Member Organization)" campaign, which is promoting public awareness and understanding of aquaculture to better inform public debate. It also includes a programme specifically aimed at school children. 
At a high level EC DG Mare event in 2016, (EC, 2016b) the European Commissioner for Environment, Maritime Affairs and Fisheries expressed the ambition that these approaches and funding initiatives would help the European Union aquaculture sector to grow sustainably by 30 percent over the next 10 years.

\section{AQUACULTURE CONTRIBUTION TO THE FAO STRATEGIC OBJECTIVES}

\subsection{Status and trends}

The FAO has five strategic objectives (SO):

- Help eliminate hunger, food insecurity and malnutrition.

- Make agriculture, forestry and fisheries more productive and sustainable.

- Reduce rural poverty.

- Enable inclusive and efficient agricultural and food systems.

- Increase the resilience of livelihoods to threats and crises.

Achieving these objectives in the food and agriculture sector worldwide will contribute to the seventeen sustainable development goals under Agenda 2030:

1. No poverty

2. Zero hunger

3. Good health and well-being

4. Quality education

5. Gender equality

6. Clean water and sanitation

7. Affordable and clean energy

8. Decent work and economic growth

9. Industry, innovation and infrastructure
10. Reduced inequalities

11. Sustainable cities and communities

12. Responsible consumption and production

13. Climate action

14. Life below water

15. Life on land

16. Peace, justice and strong institutions

17. Partnerships for the goals

Depending on the specific context, the European aquaculture sector can contribute to all of these strategic objectives. The following paragraphs describe the ways in which strategic objectives are addressed by various attributes of the industry (specific SOs are identified by italicised script).

Aquaculture provides a means to reduce hunger and improve nutrition, alleviate poverty, generate economic growth and ensure better use of natural resources - areas relevant to multiple goals of the 2030 Agenda. In particular, aquaculture is a major component of FAO's Blue Growth Initiative which aims at harmonising the environmental, social and economic aspects of living aquatic resources to ensure equitable benefits for communities. In particular it aims at offering decent work opportunities to fish farmers, in particular youth, while simultaneously boosting income and nutrition security and safeguarding natural resources (reduction in rural poverty; increasing the resilience of livelihoods to threats and crises).

Aquaculture in Europe has served to increase the overall amount of fish produced in the region. Although aquaculture remains a much smaller supplier of fish than capture fisheries, its contribution has risen (CAGR of 3.4 percent) to increase its proportional supply of total fish from 13.7 percent to 18.5 percent, representing a CAGR of 0.37 percent. Since per capita consumption has not increased by a corresponding amount, the implication is a reduced demand for imported fish products (reducing food insecurity in the region).

The dominant cultured species in Europe is Atlantic salmon whose relatively high content of longchain omega 3 fatty acids ranks it amongst the most nutritious of fish protein sources (contributing to avoidance of malnutrition). Whilst still regarded as a luxury product, the competitive demands of 
large-scale farming have resulted in a constant drive to reduce costs. In real terms, the retail price of salmon has fallen considerably over the last 30 years, benefiting both European consumers and importers of European salmon (contributing to increased efficiency of food production). In their comparative analysis, Marine Harvest show the relative changes of prices of the main animal protein sources since 1980 as follows (Table 6):

Table 6. Change in real price of main animal protein re-based to 100, 1980 - 2014

\begin{tabular}{l|c|c} 
& Index prices rebased 1980 & Indexed price 2014 \\
\hline Chicken & 100 & 335 \\
\hline Beef & 100 & 170 \\
\hline Lamb & 100 & 90 \\
\hline Pork & 100 & 77 \\
\hline Salmon & 100 & 69 \\
\hline
\end{tabular}

Source: Marine Harvest, 2015.

Most European aquaculture operations are making great strides to address the objectives of sustainability within the Blue Growth Initiative. Effluent levels are strictly controlled through the Water Framework Directive or the Maritime Spatial Planning Directive, and the major environmental problems that remain in the industry are being addressed through well-resourced research and development and investment in new and innovative technologies (sustainability). In order for companies to obtain consent to expand, or for research institutions to obtain funding for their work from the public sector, it is a fundamental requirement that the work complies with the strategic objectives of the Common Fisheries Policy, in the case of European Union member states, or achieves defined environmental objectives in the case of the Kingdom of Norway.

The undesirable demands of the culture of mainly carnivorous fish on fishmeal and fish oil have been greatly ameliorated by strategic substitution with plant-derived products (Section 6). The combined proportion of fish oil and fish meal in salmon diets has dropped from 90 percent to under 30 percent over 25 years, and continuing research and development e.g. with oils from transgenic crops implies the potential for continuing reduction in dependence upon industrial fishing for aquaculture feed components (sustainability).

STECF (2014a) estimates European Union aquaculture production to involve between 14 and 15 thousand enterprises and employ around 80000 people. However, this masks substantial differences between sectors. The United Kingdom of Great Britain and Northern Ireland salmonid sector for instance has a productivity of 127 tonnes and more than Euro 530000 per FTE. In contrast, the French oyster sector produces 19 tonnes and Euro 84800 per FTE whilst the Romanian carp sector produces 3.9 tonnes and Euro 6180 per FTE. This suggests that growth in the salmon sector has less impact on employment than growth in shellfish or freshwater production. However, it is important to also take into account the processing sector where, for example, a tonne of salmon production will create more jobs than a tonne of carp or oysters. Overall employment in fish processing in the European Union (Member Organization) is around 120000 jobs (STECF, 2014b); (reduction in rural poverty; increasing the resilience of livelihoods to crises).

\subsection{The way forward}

Much aquaculture development in Europe will be governed by the revised European Union CFP and the European Union Blue Growth Strategy, which has a greater focus on economic development. In most non-member states, there are largely equivalent policies. The revised CFP and its Strategic Guidelines for the sustainable development of the European Union aquaculture (EC, 2013) are intended to stimulate and guide aquaculture development in Europe, such that it "can contribute to the overall objective of filling the gap between the European Union (Member Organization) consumption and production of seafood in a way that is environmentally, socially and economically sustainable". 
There is no doubt that the employment created by aquaculture, particularly in relatively isolated coastal communities in the Kingdom of Norway, Scotland, the Hellenic Republic, and the Republic of Turkey is of tremendous importance in maintaining or increasing the economic and social viability of such communities. Furthermore, the relatively planned and controlled nature of aquaculture in comparison with fishing gives much greater social stability in rural coastal communities. Further progress in job creation may come through potential for better use of waste products, integration of aquaculture with renewable energy, conservation, tourism or other activities.

\section{REFERENCES}

Arthur, G. 2016. Mussel hatchery developments in Shetland - securing future seed supplies. Presentation to annual meeting of Association of Scottish Shellfish Growers, $7^{\text {th }}$ October 2016.

Ashton, T. 2016. Genetic selection opportunities for the shellfish industry. Presentation to annual meeting of Association of Scottish Shellfish Growers, $7^{\text {th }}$ October 2016 BBC. 2016.

BBC. 2016. Scottish Sea Farms starts sea lice device trials. Business News UK. Available at www.bbc.co.uk/news/uk-scotland-scotland-business-36815399?SThisFB [16 ${ }^{\text {th }}$ July 2016].

Betancor, M.B., Sprague, M., Usher, S., Sayanova, O., Campbell, P.J., Napier, J.A. \& Tocher, D.R. 2015. A nutritionally-enhanced oil from transgenic Camelina sativa effectively replaces fish oil as a source of eicosapentaenoic acid for fish. Sci. Rep., 5: Article number: 8104.

Borrello, A., Natale, F. \& Motova, A. 2014. European Trade of Fisheries and Aquaculture Products. JRC Science and Policy Report EUR 26957 EN. Luxembourg. Publications Office of the European Union. Also available at: http://publications.jrc.ec.europa.eu/repository/handle/JRC92724

Bostock, J., Lane, A., Hough, C. \& Yamamoto, K. 2016. An assessment of the economic contribution of EU aquaculture production and the influence of policies for its sustainable development. Aquac. Int., 24(3): 699-733.

Bush, S.R., Belton, B., Hall, D., Vandergeest, P., Murray, FJ., Ponte, S., Oosterveer, P., Islam, M.S., Mol, A.P.J., Hatanaka, M., Kruijssen, F., Ha, T.T.T., Little, D.C. \& Kusumawati, R. 2013. Certify Sustainable Aquaculture? Science, 341(6150): 1067-1068.

Cataudella, S., Crosetti, D. \& Massa, F. eds. 2015. Mediterranean coastal lagoons: sustainable management and interactions among aquaculture, capture fisheries and the environment. Studies and Review. General Fisheries Commission for the Mediterranean. No 95. Rome. 278 pp.

De la Gándara, F., Ortega, A. \& Buentello, A. 2016. Tuna Aquaculture in Europe. In: D. Benetti, G. Partridge and A. Buentello, eds., Advances in Tuna Aquaculture. pp. 115-157, Ch. 6. Oxford, UK: Academic Press

EAS. 2016. Growing larger fish in RAS. European Aquaculture Society annual meeting, Edinburgh, September 2016. Available

at: https://www.youtube.com/watch?v=dRUeupJLTkU\&feature=youtu.be

EATiP. 2012. The future of European aquaculture. Our vision - a strategic agenda for research and innovation. Available at: www.eatip.eu/Default.asp?SHORTCUT $=92$

EATiP. 2014. Performance of the sea bass and sea bream sector in the Mediterranean. Paper presented at 2014. Available at: www.eatip.eu/shortcut.asp?FILE=1222.

EC. 2016. European Economic Forecast. Spring 2016. Institutional Paper 025/May 2016. Luxembourg: Publications Office of the European Union, 2016. Also available at http://ec.europa.eu/economy_finance/publications/eeip/pdf/ip025_en.pdf

EC. 2016b. Tapping into blue growth: the way forward for European aquaculture. In DG Mare (Ed.), Aquaculture High Level Event Report, 24 May 2016, Square Brussels Meeting Centre. (p. 21). Brussels: European Commission.

EC. 2013. Communication from the commission to the European Parliament, The Council, The European Economic and Social Committee and The Committee of the Regions. Strategic Guidelines for the sustainable development of EU aquaculture. COM(2013) 229. Brussels, 29.4.2013. Also available http://ec.europa.eu/fisheries/cfp/aquaculture/official_documents/com_2013_229_en.pdf 
Eurofish. 2016. Overview of the Turkish fisheries and aquaculture sector. (available at: http://eurofish.dk/ efweb/index.php?option=com_content\&view=article\&id=123\%3Aturkey\&ca tid=37\&Itemid=59)

European Parliament. 2009. Directorate General for internal policies. Regulatory and legal constraints for European Aquaculture 2009.

FAO. 2012. General Fisheries Commission for the Mediterranean. 2012. Report of the thirty-sixth session. Marrakech, Morocco, 14-19 May 2012. GFCM Report. No 36. Rome FAO. 71 pp.

FAO. 2016a. Low-Income Food-Deficit Countries (LIFDC) - List for 2015. Available at: www.fao.org/countryprofiles/lifdc/en/

FAO. 2016b. Fishery and Aquaculture Statistics. [Global aquaculture production - Quantity (1950 2014) and Value (1984-2014)]. (FishStatJ). In FAO Fisheries and Aquaculture Department [online or CD-ROM]. Rome. Available at www.fao.org/fishery/statistics/software/fishstatj/en

FAO. 2016c. Report of the thirty-ninth session of the General Fisheries Commission for the

Mediterranean (GFCM), Milan, Italy, 25-29 May 2015. GFCM Report No. 39. Rome, Italy

FishBoost. 2014. Fish Boost. Boosting European aquaculture by advancing selective breeding to the next levels. Available at: www.fishboost.eu/

Garay Krogh, O. 2016. RAS in salmon farming industry. Presentation given at the European Aquaculture Society industry forum Edinburgh, $22^{\text {nd }}$ September 2016. Available at: www.youtube.com/watch?v=dRUeupJLTkU\&feature=youtu.be

Gubbins, M., Bricknell, I. \& Service, M. 2013. Impacts of climate change on Aquaculture. MCCIP Sci. Rev.: 318-327.

Hersoug, B. 2015. The greening of Norwegian salmon production. Marit. Stud., 14(1): 1-19.

HLPE. 2014. Sustainable fisheries and aquaculture for food security and nutrition. A report by the High Level Panel of Experts on Food Security and Nutrition of the Committee on World Food Security, Rome 2014.

Hixson, S.M., Parrish, C.C. \& Anderson, D.M. 2014. Full substitution of fish oil with camelina (Camelina sativa) oil, with partial substitution of fish meal with camelina meal, in diets for farmed Atlantic salmon (Salmo salar) and its effect on tissue lipids and sensory quality. Food Chemistry, 157: 51-61.

Hjul, J. 2016. Akva to explore submersible farming. FishUpdate. (available at: http://www.fishupdate.com/akva-to-explore-submersible-farming/). [1 ${ }^{\text {st }}$ February 2016]

Holmyard, J. 2015. Mussel cultivation - risks and challenges of volume production. Paper presented at Association of Scottish Shellfish Growers Annual Conference, Oban 2015. Available at: http://assg.org.uk/\#/conf-papers-15/4591048983

ICES. 2012. International Council for the Exploration of the Sea. Report of the Working Group on Marine Shellfish Culture 20-23 March 2012, Sopot, Poland. ICES CM 2012/SSGHIE: 15. 117 pp. Available

at http://ices.dk/sites/pub/Publication\%20Reports/Expert\%20Group\%20Report/SSGHIE/2012/WG MASC12.pdf

Jackson, D. 2013. The effect of fragmented legislation on the aquaculture sector. Presentation. Available at: www.niva.no/www/niva/resource.nsf/files/3123235904jackson_the_effects_of_fragmented_legislation_on_the_aquaculture_sector/\$FILE/jackson_the_ effects_of_fragmented_legislation_on_the_aquaculture_sector.pdf

Jansen, H., Van Den Burg, S., Jak, R., Kamermans, P., Poelman, M. \& Stuiver, M. 2016. The feasibility of offshore aquaculture and its potential for multi-use in the North Sea. Aquaculture International (2016) 24: 735. doi:10.1007/s10499-016-9987-y

Janssen, K., Chavanne, H., Berentsen, P. \& Komen, H. 2015. European seabass (Dicentrarchus labrax) - Current status of selective breeding in Europe. FISHBOOST Project. Available at: www.fishboost.eu/uploads/2/5/8/8/25888062/european_seabass__current_status_of_selective_breeding_in_europe.pdf

Kaiser, M., \& Stead, S. M. 2002. Uncertainties and values in European aquaculture: communication, management and policy issues in times of "changing public perceptions." Aquaculture International, 10(6), 469-490. http://doi.org/10.1023/A:1023963326201

Marine Harvest. 2015. Salmon Farming Industry Handbook 2015. Marine Harvest ASA. Available at: http://hugin.info/209/R/1934071/696335.pdf 
Marine Harvest. 2016. Salmon Farming Industry Handbook 2016. Marine Harvest ASA. Available at: www.marineharvest.com/globalassets/investors/handbook/2016-salmon-industry-handbookfinal.pdf

Marine Scotland. 2013. Gyrodactylus salaris. Topic sheet no 32 v3. Available at: www.gov.scot/Resource/0043/00432568.pdf

Marine Scotland. 2015. A Technical Standard for Scottish Finfish Aquaculture. Developed by the Ministerial Group for Sustainable Aquaculture's Scottish Technical Standard Steering Group. Edinburgh: The Scottish Government. Available at: www.gov.scot/Resource/0047/00479005.pdf

Murray, F., Bostock, J. \& Fletcher, D. 2014. Review of Recirculation Aquaculture System Technologies and their Commercial Application. Prepared for Highlands and Islands Enterprise. Available at: www.hie.co.uk

Norway. 2016. Aquaculture Statistics. Directorate of Fisheries. Available at: www.fiskeridir.no/English/Aquaculture/Statistics/Total

OECD. 2016. Norway - Economic forecast summary (June 2016). Available at: www.oecd.org/economy/norway-economic-forecast-summary.htm

p.a.u. education. 2014. Communication Campaign on Aquaculture in the European Union : Analysis of International Campaigns on Aquaculture. Brussels. Available at http://ec.europa.eu/fisheries/cfp/emff/legislation/doc/2015-03-10-analysis-of-internationalcampaigns-on-aquaculture_en.pdf

Potts, J., Wilkings, A., Lynch, M. \& McFatridge, S. 2016. State of Sustainability Initiatives Review: Standards and the blue economy. International Institute for Sustainable Development (IISD). 209 pp. Available at: www.iisd.org/sites/default/files/publications/ssi-blue-economy2016.pdf

PrimeFish. 2015. Project description. (available at: http://www.primefish.eu/project-description).

Prevent Escape. 2014. Prevent Escape (2014) PREVENT ESCAPE CORDIS Project Compendium. Available at http://preventescape.eu

Ramsden, N. 2016. Marine Harvest will select just one of its offshore solutions for the future. Undercurrent News. (available at https://www.undercurrentnews.com/2016/06/15/marineharvest-will-select-just-one-of-its-offshore-solutions-for-the-future/).

Ross, L.G., Telfer, T.C., Falconer, L., Soto, D. \& Aguilar-Manjarrez, J., eds. 2013. Site selection and carrying capacities for inland and coastal aquaculture. FAO/Institute of Aquaculture, University of Stirling, Expert Workshop, 6-8 December 2010. Stirling, the United Kingdom of Great Britain and Northern Ireland. FAO Fisheries and Aquaculture Proceedings No. 21. Rome, FAO. 46 pp. Includes a CD-ROM containing the full document (282 pp.)

Russian Federation. 2014. Summary of the State Programme of The Russian Federation,

"Fisheries Sector Development"(in Russian). Available www.fish.gov.ru/files/documents/otraslevaya_deyatelnost/ekonomika_otrasli/gos_programma/go sprogramma.pdf

Sanchez-Jerez, P., Karakassis, I., Massa, F., Fezzardi, D., Aguilar-Manjarrez, J., Soto, D., Chapela, R., Avila, P., Macias, J.C., Tomassetti, P., Marino, G., Borg, J.A., Franičević, V., Yücel Gier, G, Fleming, I.A., Biao, X., Nhhala, H., Hamza, H., Forcada, A., Dempster, T. 2016. Aquaculture's struggle for space: the need for coastal spatial planning and the potential benefits of Allocated Zones for Aquaculture (AZAs) to avoid conflict and promote sustainability. Aquacult Environ Interact, Vol. 8: 41-54. Available at: www.intres.com/articles/aei2016/8/q008p041.pdf

Scott, D., McLeod, D., Young, J., Brown, J., Immink, A. and Bostock, J. 2010. A study of the prospects and opportunities for shellfish farming in Scotland. Study funded by Marine Scotland and undertaken by Stirling Aquaculture. Available at: www.gov.scot/resource/doc/295194/0118352.pdf

Scottish Government. 2011. Gyrodactylus salaris, contingency plan. Fourth edition, March 2011. Available at: www.gov.scot/resource/doc/1062/0115961.pdf

Science for Environment Policy. 2015. Sustainable Aquaculture. Future Brief 11. Brief produced for the European Commission DG Environment by the Science Communication Unit, UWE, Bristol. Available at: http://ec.europa.eu/science-environment-policy 
Seiche, K., Gerdeaux, D., Gwiazda, R., Lévai, F., Musil, P., Nemenonoks, O., Strod, T. \& Carss, D.N. 2015. Cormorant-fisheries conflicts in Carp pond areas in Europe and Israel. An INTERCAFE Overview. Available at: www.intercafeproject.net/pdf/Carp_Ponds_Manual_FOR_WEB.pdf

Shepherd, C.J. \& Little, D.C. 2014. Aquaculture: Are the Criticisms Justified? II - Aquaculture's environmental impact and use of resources, with specific reference to farming Atlantic Salmon. World Agriculture 4(2), 37-52.

Soares, S., Murray, A.G., Crumlish, M., Turnbull, J.F. \& Green, D.M. 2012. Evaluating abnormal mortality as an indicator of disease presence in the Atlantic salmon industry using the receiver operating characteristic (ROC) Aquaculture. 370-371:136-143.

Standard Norge. 2009. Marine fish farms - Requirements for site survey, risk analyses, design, dimensioning, production, installation and operation. Adopted $10^{\text {th }}$ November 2009. (available at http://www.standard.no/en/nyheter/news-in-english/2012/marine-fish-farms/\#.V-6BgIgrJMx)

STECF. 2014a. The Economic Performance of the EU Aquaculture Sector EC Joint Research Centre, Scientific, Technical and Economic Committee for Fisheries (STECF 14-18). Publications Office of the European Union, Luxembourg, EUR 27033 EN, JRC 93169, 451 pp.

STECF. 2014b. The Economic Performance of the EU Fish Processing Industry. EC Joint Research Centre, Scientific, Technical and Economic Committee for Fisheries. Publications Office of the European Union, Luxembourg, EUR 27029 EN, JRC 93340, 355 pp.

Stündl, L., Szücs, I., Bardocz, T. \& Mihalffy, Sz. 2014. The Hungarian multiannual aquaculture strategic plan and its relation to the Europe 2020 strategy. Presentation to Aquaculture Europe 2014, Donostia-San Sebastian, Spain. October 14-17, 2014. Available at: www.was.org/easonline/documents/MeetingPresentations/AE2014/AE2014_0740.pdf

Tallaksen, E. 2014a. Selonda leads the way in restructuring of Greek businesses. Undercurrent News. Available at: www.undercurrentnews.com/2014/09/15/selonda-leads-the-way-in-restructuring-ofgreek-businesses/ [15th Sept 2014].

Tallaksen, E. 2014b. Shareholders give green light to Selonda bank takeover; Stephanis steps down as CEO. Undercurrent Available at: www.undercurrentnews.com/2014/09/11/shareholders-give-green-light-to-selonda-banktakeover-stephanis-steps-down-as-ceo/ [11 ${ }^{\text {th }}$ September 2014].

Teletchea, F. 2015. Domestication of Marine Fish Species: Update and Perspectives. Journal of Marine Science and Engineering, 3(4): 1227-1243.

The World Bank. 2016a. World DataBank. World Development Indicators. Available at: http://databank.worldbank.org/data/reports.aspx?source=world-development-indicators

The World Bank. 2016b. Turkey Overview. Available at: www.worldbank.org/en/country/turkey/overview

Thorstad, E.B., Fleming, I.A., McGinnity, P., Soto, D., Wennevik, V. \& Whoriskey, F. 2008. Incidence and impacts of escaped farmed Atlantic salmon Salmo salar in nature. NINA Special Report 36. 110 pp.

Thorstensen, V., Weissinger, R. \& Sun, X. 2015. Private Standards-Implications for Trade, Development, and Governance. Task Force on Regulatory Systems Coherence. The E15 Initiative - Strengthening the global trade and investment system for sustainable development. Geneva: International Centre for Trade and Sustainable Development \& World Economic Forum. 18 pp. Available at www.e15initiative.org

Torrissen, O., Jones, S., Asche, F., Guttormsen, A., Skilbrei, O.T., Nilsen, F., Horsberg, T.E. \& Jackson, D. 2013. Salmon lice - impact on wild salmonids and salmon aquaculture. J. Fish Dis., 36(3): 171-194.

Turnbull, J.F., Berrill, I.K., Green, D.M., Kaye, R., Morris, D., Murray, A.G., del-Pozo, J. \& Shinn, A. 2011. Applied epidemiology with examples from UK aquaculture. Aquaculture Research. 42: 21-27.

USDA. 2016. Development of Aquaculture Sector in Russia. GAIN Report Number: RS1609. Moscow. Available at: http://gain.fas.usda.gov/Recent GAIN Publications/Development of Aquaculture Sector in Russia_Moscow_Russian Federation_2-26-2016.pdf

Vandergeest, P. \& Unno, A. 2012. A new extraterritoriality? Aquaculture certification, sovereignty, and empire. Political Geography. 31(6): 358-367. 
Váradi, L., Lane, A., Harache, Y., Gyalog, G., Békefi, E. \& Lengyel, P. 2011. Regional review on status and trends in aquaculture development in Europe - 2010. FAO Fisheries and Aquaculture Circular. No. 1061/1. Rome, FAO. 2010. 129 pp. Available at: www.fao.org/docrep/014/i2211b/i2211b.pdf

Váradi, L. 2011. Aquaculture innovation in Hungary. Report of Informal Meeting of the EU Directors General for Fisheries in Hungary, $6^{\text {th }}$ of June, 2011. Available at: http://halaszat.kormany.hu/download/e/51/20000/Aquaculture\%20Innovation\%20in\%20Hungary .pdf

Ytrestøyl, T., Aas, T.S. \& Åsgård, T. 2015. Utilisation of feed resources in production of Atlantic salmon (Salmo salar) in Norway. Aquaculture, 448: 365-374. 
ISBN 978-92-5-109652-9 ISSN 2070-6065 